\title{
Cretaceous carbonatites of the southeastern Brazilian Platform: a review
}

\author{
Celso de Barros Gomes ${ }^{1 *}$, Piero Comin-Chiaramonti ${ }^{2}$, Rogério Guitarrari Azzone ${ }^{1}$, \\ Excelso Ruberti ${ }^{1}$, Gaston Eduardo Enrich Rojas ${ }^{1}$
}

\begin{abstract}
This paper reviews general aspects of alkaline-carbonatitic rocks of Brazilian, Paraguayan and Bolivian terrains. Although 30 such occurrences are known in literature, only the major ones have been thoroughly investigated. The carbonatites are of Cretaceous age, with two well-defined Lower Cretaceous and Upper Cretaceous generation episodes. A clear tectonic control by ancient structural features such as archs, lineaments and faults characterizes most cases. The rocks exhibit a large compositional variation, in decreasing orders of abundance from calciocarbonatites to magnesiocarbonatites to ferrocarbonatites. In some complexes, they form multistage intrusions. $C-O$ isotopes indicate that, in general, the carbonatites were affected by post-magmatic processes associated with the topographic level of emplacement and low-temperature $\mathrm{H}_{2} \mathrm{O}-\mathrm{CO}_{2}$ rich fluids responsible for the increased amount of heavy carbon and oxygen. Sr-Nd isotopic compositions similar to those of coeval alkaline silicate rocks, ranging from depleted to enriched mantle sources, have been influenced by two distinct metasomatic events in Proterozoic at 2,0-1.4 Ga and 1.0-0.5 Ga. Sr-Nd-Pb-Os data seem related to an isotopically enriched source, their chemical heterogeneities reflecting a depleted mantle that was metasomatized by small-volume melts and by fluids rich in incompatible elements. Fractional crystallization and liquid immiscibility are believed to be the most effective processes in the formation of the Cretaceous carbonatites, with minor contribution of crustal contamination. Pb isotopic ratios yield evidence that HIMU and EM I mantle components played an important role in the genesis of the carbonatitic magma.
\end{abstract}

KEYWORDS: Carbonatites; Alkaline Rocks; Brazilian Platform.

\section{INTRODUCTION}

Only a few review papers dealing specifically with Cretaceous carbonatites of the southeastern Brazilian Platform are known in literature. Studies by Rodrigues and Lima (1984), Berbert (1984), and Gomes et al. (1990) are among the first ones. More recently, papers such as those by Castorina et al. (1996, 1997), Comin-Chiaramonti et al. (2005c, 2014) and a general review by Comin-Chiaramonti et al. (2007a), including some African occurrences in Angola and Namibia, became available. The associated silicate alkaline rocks, on the other hand, have more frequently been reviewed (Ulbrich \& Gomes 1981, Woolley 1987, Morbidelli et al. 1995, Comin-Chiaramonti et al. 2005a, 2005d, 2007b, 2015, Brod et al. 2005, Gomes et al. 2011a, 2011b, 2013, Gomes \& Comin-Chiaramonti 2017, etc.).

According to Gomes and Comin-Chiaramonti (2017), a total of 30 carbonatite occurrences have been described, most of them in Brazilian terrains (23), but also in Paraguay (6) and Bolivia (1) (Table 1). Included are carbonate ocelli in a few occurrences of fine-grained and intrusive rocks. Carbonatites are predominantly represented by intrusive and hypabissal bodies, only two groups of volcanic occurrences having been described: the lava flows of Santo Antônio da Barra, in Goiás (Gaspar \& Danni 1981, Moraes 1988), and those of Sapucai, in Paraguay (CominChiaramonti et al. 1992). Volcanic occurrences are scarcely present, probably due to intense erosion (Morbidelli $e t$ al. 1995, Comin-Chiaramonti et al. 2005c). Carbonatites concentrate in two well-delimited areas of the Brazilian territory: the Ribeira Valley in the southeast (Ruberti $e t$ al. 2005, Gomes et al. 2011a) and the Alto Paranaíba in the central-west (Araújo et al. 2001, Guarino et al. 2013). Over the last years, these rocks have also been described near the city of Bagé (Joca Tavares and Porteira bodies; Toniolo et al. 2013, Monteiro et al. 2016) and also in

IInstituto de Geociências, Universidade de São Paulo - USP, São Paulo (SP), Brazil. E-mails: cgomes@usp.br, rgazzone@usp.br, exrubert@usp.br, gastonenrich@usp.br 2Dipartimento di Matematica e Geoscienze, Università degli Studi di Trieste, Trieste, Italia. E-mail: piero.cominchiaramonti@gmail.com

*Corresponding author.

Manuscript ID: 20170213. Received on: 10/10/2017. Approved on: 01/30/2018. 
Table 1. General information on the carbonatite occurrences of different regions of Brazil, Paraguay and Bolivia.

\begin{tabular}{|c|c|c|c|c|c|c|}
\hline Locality & & Occurrence & Petrography & Mineralogy & Age & References \\
\hline \multicolumn{7}{|l|}{ BRAZIL } \\
\hline \multicolumn{7}{|c|}{ Ribeira Valley } \\
\hline 1 & $\begin{array}{l}\text { Barra do } \\
\text { Itapirapuã }\end{array}$ & $\begin{array}{l}\text { Dike, vein, } \\
\text { breccia }\end{array}$ & $\begin{array}{l}\text { Mg-ca, Fe-ca, Si-ca, } \\
\text { Ca-ca, Fe, S, L }\end{array}$ & $\begin{array}{c}\text { Do, Ank, Cc, Phl, Pr, Qz, } \\
\text { Ap, Bas, Pa, Syn, AB, } \\
\text { Ga, Sph }\end{array}$ & $\begin{array}{c}\text { Lower } \\
\text { Cretaceous }\end{array}$ & $1-19$ \\
\hline 2 & Ipanema & Dike, vein & $\begin{array}{c}\text { Ca-ca } \\
\text { Gl, Sh, Di, S, Fe, Te }\end{array}$ & $\begin{array}{c}\text { Cc, Phl, Op, Ap, Cpx, } \\
\text { Amp, Ba, Sf }\end{array}$ & $\begin{array}{c}\text { Lower } \\
\text { Cretaceous }\end{array}$ & $\begin{array}{c}2-6,12,13,15 \\
18-26,59\end{array}$ \\
\hline 3 & $\begin{array}{c}\text { Itanhaém (Ilha } \\
\text { das Cabras or } \\
\text { Givura) }\end{array}$ & Dike & Mg-ca & $\begin{array}{l}\text { Do, } \mathrm{Ap}, \mathrm{Phl}, \mathrm{Pv}, \mathrm{Gr} \\
\text { alterated mafics }\end{array}$ & $\begin{array}{c}\text { Lower } \\
\text { Cretaceous }\end{array}$ & $\begin{array}{c}2,4-6,18,19 \\
21,23,24,27 \\
28,59\end{array}$ \\
\hline 4 & Itapirapuã & $\begin{array}{l}\text { Dike, vein, } \\
\text { breccia }\end{array}$ & $\begin{array}{c}\text { Ca-ca } \\
\text { NS, I-Mel, Ti }\end{array}$ & Cc, Ap, AF, Ne, Mt, Pt & $\begin{array}{c}\text { Lower } \\
\text { Cretaceous }\end{array}$ & $\begin{array}{c}2,4-6,12,13 \\
18,-19,21,23 \\
24,29-32,59\end{array}$ \\
\hline 5 & Jacupiranga & Plug, dike & $\begin{array}{c}\text { Ca-ca, Mg-ca } \\
\text { Du, Py (Ja), I-Mel, Tr, E, } \\
\text { Mz, Fe, Sd, S, A, AB }\end{array}$ & $\begin{array}{c}\text { Cc, Do, Phl, Ol, Mt, Ap, } \\
\text { Pr, Il, Pv, Pyr, Ga, Cl, } \\
\text { Ne, Amp }\end{array}$ & $\begin{array}{c}\text { Lower } \\
\text { Cretaceous }\end{array}$ & $\begin{array}{l}2-6,12-15 \\
18,19,21,23 \\
24,33-48,59\end{array}$ \\
\hline 6 & $\begin{array}{l}\text { Juquiá } \\
\text { (Serrote) }\end{array}$ & Plug, dike & $\begin{array}{c}\text { Mg-ca, Ca-ca } \\
\text { Py, AG, I-Mel, NS, S, Sd, } \\
\text { AB, Te, Pho, Fe }\end{array}$ & $\begin{array}{l}\text { Do, Ank, Cc, Phl, Mt, } \\
\text { Ba, Ap, Mo, Anc, No }\end{array}$ & $\begin{array}{c}\text { Lower } \\
\text { Cretaceous }\end{array}$ & $\begin{array}{c}2-6,12-15,18 \\
19,21,23,24 \\
41,49-52,59\end{array}$ \\
\hline 7 & Mato Preto & Plug, breccia & $\begin{array}{c}\text { Ca-ca, Fe-ca } \\
\text { NS, Ti, Pho, Ga, I, Mel, } \\
\text { L, Ta }\end{array}$ & $\begin{array}{c}\text { Cc, Ank, Mt, Ap, Pr, Ba, } \\
\text { Fl, Qz, AF, Flca }\end{array}$ & $\begin{array}{c}\text { Lower } \\
\text { Cretaceous }\end{array}$ & $\begin{array}{c}1,2,4-8,12-19 \\
21,24,27,53- \\
57,59\end{array}$ \\
\hline 8 & Piedade & & & & $\begin{array}{c}\text { Lower } \\
\text { Cretaceous }\end{array}$ & $12,21,58,59$ \\
\hline \multicolumn{7}{|c|}{ São Paulo Coast Line } \\
\hline 9 & Ilhas & Dike & Mg-ca, Si-ca & $\begin{array}{l}\text { Cc, Do, Phl, Ap, } \\
\text { phyllosilicates }\end{array}$ & n.d. & 60 \\
\hline \multicolumn{7}{|c|}{ Cabo Frio Lineament } \\
\hline 10. & $\begin{array}{l}\text { Poços de } \\
\text { Caldas }\end{array}$ & Dike, breccia & $\begin{array}{c}\text { Si-ca, ocelli in } \\
\text { lamprophyre } \\
\text { NS, Ti, Pho, L, La, Lp, }\end{array}$ & Cc, Pr, Phl & $\begin{array}{c}\text { Upper } \\
\text { Cretaceous }\end{array}$ & $\begin{array}{c}2,5,21,59 \\
61-63\end{array}$ \\
\hline \multicolumn{7}{|c|}{ Santa Catarina } \\
\hline 11 & Anitápolis & $\begin{array}{l}\text { Plug, dike, } \\
\text { vein }\end{array}$ & $\begin{array}{c}\text { Ca-ca, Mg-ca } \\
\text { Py, Biot, I-Mel, NS, } \\
\text { Phos, Fe, Apt, Ne, L, Pho }\end{array}$ & $\begin{array}{c}\text { Cc, Do, Ap, Mt, Ol, Phl, } \\
\text { Pr, Bd, Qz, Al, Anc, } \\
\text { Bas, Sf }\end{array}$ & $\begin{array}{c}\text { Lower } \\
\text { Cretaceous }\end{array}$ & $\begin{array}{c}2-6,13-15,18 \\
19,21,23,24 \\
59,64-69\end{array}$ \\
\hline 12 & Lages & $\begin{array}{l}\text { Plug, dike, } \\
\text { vein, breccia }\end{array}$ & $\begin{array}{c}\text { Fe-ca, Ca-ca } \\
\text { NS, Pho, Ba, Ne, Meli, } \\
\text { Te, Pht, Ki }\end{array}$ & $\begin{array}{l}\text { Ank, Cc, Ap, Phl, Qz, } \\
\text { AF, Pr, Pyr, Syn, Bas }\end{array}$ & $\begin{array}{c}\text { Upper } \\
\text { Cretaceous }\end{array}$ & $\begin{array}{c}2-6,13-15,19 \\
21,23,24,59 \\
70-74\end{array}$ \\
\hline \multicolumn{7}{|c|}{ Rio Grande do Sul } \\
\hline 13 & Joca Tavares & Plug? & $\mathrm{Ca}$ & $\begin{array}{c}\text { Do (Cc), Ap, Op (Hm, } \\
\text { Il), Ch }\end{array}$ & n.d. & 75,76 \\
\hline 14 & Porteira & Dike & $\mathrm{Ca}$ & $\begin{array}{l}\text { Do, Ap., Flo, Op (Hm, } \\
\text { Il), Ch }\end{array}$ & n.d. & 75,76 \\
\hline \multicolumn{7}{|c|}{ Alto Paranaíba } \\
\hline 15 & $\begin{array}{c}\text { Araxá } \\
\text { (Barreiro) }\end{array}$ & Stock, dike & $\begin{array}{l}\text { Mg-ca, Ca-ca, Fe-ca } \\
\text { Gl, Py, Phos, Sil }\end{array}$ & $\begin{array}{c}\text { Do, Cc, Ank, Str, Si, } \\
\text { Mg, Bu, Mt Ap, Phl, AF, } \\
\text { Anc, Pr, Mo, Sf }\end{array}$ & $\begin{array}{c}\text { Upper } \\
\text { Cretaceous }\end{array}$ & $\begin{array}{c}2-6,13-15,19 \\
21,23,24,59 \\
77,78\end{array}$ \\
\hline 16 & Catalão I & Dike & $\begin{array}{c}\text { Mg-ca, Ca-ca, Si-ca } \\
\text { Phl, Du, Be, Phos, NS, } \\
\text { Nel, Sil }\end{array}$ & $\begin{array}{c}\text { Do, Cc, Mg, Ap, Phl, Mt, } \\
\text { Ba, Ti, Mo, Zr, Pr, Sf, } \\
\text { Fl, No }\end{array}$ & $\begin{array}{c}\text { Upper } \\
\text { Cretaceous }\end{array}$ & $\begin{array}{c}2-6,13-15,19 \\
21,23,24,59 \\
79-81\end{array}$ \\
\hline 17 & Catalão II & Stock & $\begin{array}{c}\text { Ca-ca, Mg-ca } \\
\text { Py, Gl, Phos, Apt, Mgt, } \\
\text { Fe, S, L, Sil }\end{array}$ & $\begin{array}{c}\text { Cc, Phl, Ver, AF, Mt, } \\
\text { Pr, Ba, Pyr, REE } \\
\text { minerals }\end{array}$ & $\begin{array}{c}\text { Upper } \\
\text { Cretaceous }\end{array}$ & $\begin{array}{c}2-6,13-15 \\
19,21,23,24 \\
59,81\end{array}$ \\
\hline
\end{tabular}

Continue... 
Table 1. Continuation.

\begin{tabular}{|c|c|c|c|c|c|c|}
\hline Locality & & Occurrence & Petrography & Mineralogy & Age & References \\
\hline 18 & Salitre & $\begin{array}{l}\text { Stock, dike, } \\
\text { vein }\end{array}$ & $\begin{array}{c}\text { Ca-ca, Mg-ca } \\
\text { Be, Py, Du, Phos, NS, } \\
\text { S, Ti, T }\end{array}$ & $\begin{array}{c}\text { Cc, Do, Ap, Mt, Phl, Ol, } \\
\text { Pr, Zr, Ba, Sf }\end{array}$ & $\begin{array}{c}\text { Upper } \\
\text { Cretaceous }\end{array}$ & $\begin{array}{c}2-6,13-15 \\
21,23,24,59 \\
81-86\end{array}$ \\
\hline 19 & Tapira & $\begin{array}{l}\text { Stock, dike, } \\
\text { vein }\end{array}$ & $\begin{array}{c}\text { Ca-ca, Mg-ca } \\
\text { Be, Du, Pe, Py, Phos, S, } \\
\text { T, Melil, Ka }\end{array}$ & $\begin{array}{c}\text { Cc, Do, Ap, Phl, Mt, Pr, } \\
\text { Il, Pv, Ti, Pyr }\end{array}$ & $\begin{array}{c}\text { Upper } \\
\text { Cretaceous }\end{array}$ & $\begin{array}{c}2-6,13-15,19 \\
21,23,24,59 \\
81,87-90\end{array}$ \\
\hline 20 & Serra Negra & Plug & $\begin{array}{c}\text { Ca-ca } \\
\text { Du, Be, Sh, Py (Ja), Ti, } \\
\text { T, Fe }\end{array}$ & $\mathrm{Cc}, \mathrm{Mt}, \mathrm{Ap}, \mathrm{Pr}, \mathrm{Pv}, \mathrm{Bd}$ & $\begin{array}{l}\text { Upper } \\
\text { Cretaceous }\end{array}$ & $\begin{array}{c}2-6,13,21, \\
23,24,59,81, \\
91-93\end{array}$ \\
\hline \multicolumn{7}{|l|}{ Goiás } \\
\hline 21 & Caiapó & Plug, breccia & $\begin{array}{c}\text { Mg-ca, Ca-ca, Fe-ca } \\
\text { I, L, Fe }\end{array}$ & $\begin{array}{l}\text { Do, Cc, Ank, Si, Ap, } \\
\text { Mt, Pr, AF, Qz, REE } \\
\text { minerals }\end{array}$ & n.d. & $4-6,13$ \\
\hline 22 & $\begin{array}{l}\text { Morro do } \\
\text { Engenho }\end{array}$ & Vein & $\begin{array}{c}\text { Ca } \\
\text { Py, Pe, AG, NS }\end{array}$ & Cc, Phl & n.d. & $\begin{array}{c}2,4-6,13,90 \\
94\end{array}$ \\
\hline 23 & $\begin{array}{c}\text { Santo Antônio } \\
\text { da Barra (Rio } \\
\text { Verde) }\end{array}$ & $\begin{array}{l}\text { Lava, } \\
\text { breccia, plug }\end{array}$ & $\begin{array}{c}\text { Si-ca, Ca-ca } \\
\text { Ana (?), Ka, Pho, T, } \\
\text { Phou, Mo, Br }\end{array}$ & $\begin{array}{l}\text { Cc aggregate in } \\
\text { vitreous matrix }\end{array}$ & $\begin{array}{c}\text { Upper } \\
\text { Cretaceous }\end{array}$ & $\begin{array}{c}4-6,13,21,24 \\
59,90,95-99\end{array}$ \\
\hline \multicolumn{7}{|c|}{ PARAGUAY } \\
\hline \multicolumn{7}{|l|}{ Rio Apa } \\
\hline 24 & Valle-mí & Dike & Ocelli in basanite & Cc & $\begin{array}{l}\text { Lower } \\
\text { Cretaceous }\end{array}$ & $\begin{array}{c}13,14,19,41 \\
100-106\end{array}$ \\
\hline \multicolumn{7}{|l|}{ Amambay } \\
\hline 25 & $\begin{array}{l}\text { Cerro } \\
\text { Chiriguelo } \\
\text { (Cerro } \\
\text { Corá) }\end{array}$ & Dike & $\begin{array}{l}\text { Ca-ca, Fe-ca } \\
\text { Fe, NS, T }\end{array}$ & $\begin{array}{l}\text { Cc, Ap, AB, Qz, Phl, } \\
\text { AF, Mt, Cpx, Zr, Ura, } \\
\text { Syn, Hm, Pyr, Go }\end{array}$ & $\begin{array}{l}\text { Lower } \\
\text { Cretaceous }\end{array}$ & $\begin{array}{c}2,5,13,14 \\
19,21,41,59, \\
100,102-111\end{array}$ \\
\hline 26 & Cerro Sarambí & Dike & $\begin{array}{c}\text { Ca-ca, Si-ca } \\
\text { Py, NS, Fe, Pho, T, L }\end{array}$ & Cc, Qz, Fl, Ver, Op & $\begin{array}{c}\text { Lower } \\
\text { Cretaceous }\end{array}$ & $\begin{array}{c}2,5,13,14 \\
19,41,100 \\
102-106,109 \\
111,112\end{array}$ \\
\hline \multicolumn{7}{|l|}{ Central } \\
\hline 27 & Cerro Cañada & Stock & $\begin{array}{l}\text { Ocelli in ijolite } \\
\text { AG, NS, I }\end{array}$ & $\mathrm{Cpx}, \mathrm{Ol}, \mathrm{Bi}, \mathrm{Cc}$ & $\begin{array}{l}\text { Lower } \\
\text { Cretaceous }\end{array}$ & 103-106, \\
\hline 28 & $\begin{array}{l}\text { Cerro E Santa } \\
\text { Elena }\end{array}$ & Stock & $\begin{array}{c}\text { Ocelli in ijolite } \\
\mathrm{Ga}, \mathrm{I}, \mathrm{Te}, \mathrm{Ba}, \mathrm{AB}, \mathrm{Tph}\end{array}$ & $\begin{array}{c}\text { Cpx, Ol, Mt, Amp, } \\
\text { Bi, Cc }\end{array}$ & $\begin{array}{l}\text { Lower } \\
\text { Cretaceous }\end{array}$ & 103-106-111, \\
\hline 29 & Sapucai & Lava & Mg-ca & Do, AF, Mt, Bi, Ap & $\begin{array}{l}\text { Lower } \\
\text { Cretaceous }\end{array}$ & $\begin{array}{c}41,103-106- \\
111,113\end{array}$ \\
\hline \multicolumn{7}{|l|}{ BOLIVIA } \\
\hline \multicolumn{7}{|l|}{ Velasco } \\
\hline 30 & $\begin{array}{c}\text { Cerro } \\
\text { Manomó }\end{array}$ & Dike & $\begin{array}{c}\text { Si-ca } \\
\text { NS, S, Gr, Tph, T }\end{array}$ & $\begin{array}{c}\mathrm{Si}, \mathrm{Ank}, \mathrm{Cc}, \mathrm{Go}, \mathrm{Li}, \mathrm{Qz}, \\
\text { Ap, Bas, Syn }\end{array}$ & $\begin{array}{c}\text { Lower } \\
\text { Cretaceous }\end{array}$ & $2,5,114-116$ \\
\hline
\end{tabular}

Data sources: Barra do Itapirapuã: 1, Lapido-Loureiro \& Tavares (1983); 2, Almeida (1983); 3, Berbert (1984); 4, Rodrigues \& Lima (1984); 5, Woolley (1987); 6, Gomes et al. (1990); 7, Ruberti et al. (1997); 8, Speziale et al. (1997); 9, Andrade et al. (1999a); 10, Andrade et al. (1999b); 11, Ruberti et al. (2002); 12, Ruberti et al. (2005); 13, Comin-Chiaramonti et al. (2005a); 14, Comin-Chiaramonti et al. (2005d); 15, Biondi (2005); 16, Ruberti (1998); 17, Ruberti et al. (2008); 18, Gomes et al. (2011a); 19, Comin-Chiaramonti et al. (2007a); Ipanema: 20. Leinz (1940); 21, Sonoki \& Garda (1988); 22, Davino (1975); 23, Ulbrich \& Gomes (1981); 24, Morbidelli et al. (1995); 25, Guarino et al. (2012); 26, Rugenski et al. (2006); Itanhaém: 27, Coutinho \& Ens (1992); 28, Mariano (1989); Itapirapuã: 29, Gomes \& Cordani (1965); 30, Gomes \& Dutra (1969); 31, Gomes (1970); 32, Gomes \& Dutra (1970); Jacupiranga: 33, Melcher (1966); 34, Amaral (1978); 35, Gaspar (1989); 36, Ruberti et al. (1988); 37, Roden et al. (1985); 38, Germann et al. (1987); 39, Menezes \& Martins (1984); 40, Morbidelli et al. (1986); 41, Castorina et al. (1996); 42, Santos \& Clayton (1995); 43, Huang et al. (1995); 44, Ruberti et al. (1991); 45, Gomes et al. (1996a); 46, Azzone et al. (2012); 47, Beccaluva et al. (2017); 48, Chmyz et al. (2017); Juquiá: 49, Born (1971); 50, Beccaluva et al. (1992); 51, Walter et al. (1995); 52, Azzone et al. (2013); 
Mato Preto: 53, Jenkis II (1987); 54, Santos (1988); 55, Santos et al. (1996); 56, Santos et al. (1990); 57, Comin-Chiaramonti et al. (2001); Piedade: 58, Knecht (1960); 59, Amaral et al. (1967); Ilhas: 60, Coutinho (2008); Poços de Caldas; 61, Ulbrich et al. (2002); 62, Vlach et al. (2003); 63, Ulbrich et al. (2005); Anitápolis: 64, Melcher \& Coutinho (1966); 65, Rodrigues (1985); 66, Furtado et al. (1986); 67, Furtado (1989); 68, Comin-Chiaramonti et al. (2002); 69, Scheibe et al. (2005); Lages: 70, Scheibe \& Formoso (1982); 71, Scheibe (1986); 72, Traversa et al. (1994); 73, Traversa et al. (1996); 74, Barabino et al. (2007); Joca Tavares and Porteira: 75, Toniolo et al. (2013); 76, Monteiro et al. (2016); Araxá: 77, Issa Filho et al. (1984); 78, Traversa et al. (2001); Catalão I: 79, Carvalho \& Bressan (1981); 80, Cordeiro et al. (2010); 81, Gomes \& Comin-Chiaramonti (2005); Salitre: 82, Morbidelli et al. (1997); 83, Barbosa (2009); 84, Barbosa et al. (2012a); 85, Barbosa et al. (2012b); 86, Haggerty \& Mariano (1983); Tapira: 87, Guimarães et al. (1980); 88, Brod (1999); 89, Brod et al. (2000); 90, Brod et al. (2005); Serra Negra: 91, Mariano \& Marchetto (1991); 92, Souza Filho (1974); 93, Grasso (2010); Morro do Engenho: 94, Pena (1974). Santo Antônio da Barra: 95, Gaspar \& Danni (1981); 96, Moraes (1984); 97, Moraes (1988); 98, Sgarbi (1998); 99, Junqueira-Brod et al. (2002); Valle-mí: 100, Livieres e Quade (1987); 101, Gibson et al. (1995a); 102, Gomes et al. (1996b); 103, Castorina et al. (1997); 104, Comin-Chiaramonti et al. (2007b); 105, Gomes et al. (2013); 106, Comin-Chiaramonti et al. (2014); Cerro Chiriguelo: 107, Comte \& Hasui (1971); 108, Censi et al. (1989); 109, Comin-Chiaramonti et al. (1999); 110, Gibson et al. (2006); 111, Comin-Chiaramonti et al. (2007c); Cerro Sarambí: 112, Gomes et al. (2011b); Sapucai: 113, Comin-Chiaramonti et al. (1992); Cerro Manomó: 114, Fletcher et al. (1981); 115, Comin-Chiaramonti et al. (2005b); 116, Comin-Chiaramonti et al. (2011). Other references consulted are listed in Gomes and Comin-Chiaramonti (2017).

Rock abbreviations: A, ankaratrite; AB, alkali basalt; AG, alkali gabbro; Ana, analcimite; Apt, apatitite; Ba, basanite; Be, bebedourite; Biot, biotitite; Ca, carbonatite; Ca-ca, calciocarbonatite; $\mathrm{Di}$, diorite; $\mathrm{Du}$, dunite; E, essexite: Fe, fenite; Fe-ca, ferrocarbonatite; Fou, fourchite; Ga, gabbro; Gl, glimmerite; Gr, granite; I, ijolite; Ja, jacupiranguite; Ka, kamafugite; Ki, kimberlite; L, lamprophyre; Lp, lamproite; Mel, melteigite; Meli, melilitite; Melil, melilitolite; Mgt, magnetitite; MMzd, melamonzodiorite; Mo, monchiquite; Mz, monzonite; Ne, nephelinite; Nel, nelsonite; NS, nepheline syenite; Pc, picrite; Pe, peridotite; Phl, phlogopitite; Pho, phonolite; Phos, phoscorite; Pht, phonotephrite; Py, pyroxenite; S, syenite; Sd, syenodiorite; Sh, shonkinite; Si-ca, silicocarbonatite; Sil, silexite; T, trachyte; Ta, trachyandesite; Te, tephrite; Tph, trachyphonolite; Ti, tinguaite Tr, theralite; Ur, urtite; We, wehrlite.

Mineral abbreviations: AF, alkali feldspar; Al, alstonite; Amp, amphibole; An, ancylite; Ank, ankerite; Ap, apatite; Ba, barite; Bas, bastnäesite; Bd, baddeleyite; $\mathrm{Bi}$, biotite; $\mathrm{Bu}$, burbankite; $\mathrm{Caz}$, calzirtite; $\mathrm{Cc}$, calcite; $\mathrm{Ch}$, chlorite; $\mathrm{Cl}$, clinohumite; $\mathrm{Cpx}$, clinopyroxene; Do, dolomite; $\mathrm{F}$, feldspar; Fl, fluorite; Flca, fluorocarbonates; Ga, galena; Go, goethite; Gr, garnet; Hb, hornblende; Hm, hematite; Il, ilmenite; Mg, magnesite; Mt, magnetite; Mo, monazite; Ne, nepheline; No, norsethite; Ol, olivine; Op, opaques; Pa, parisite; Phl, phlogopite; Pyr, pyrite; Pr, pyrochlore; Pt, pyrrhotite; Pv, perovskite; Sph, sphalerite; Str, strontianite; Qz, quartz; Sf, sulfide; Si, siderite; Sy, synchysite; Ti, titanite; To, thorite; Ura, uranpyrochlore; Ver, vermiculite; Zir, zirconolite; Zr, zircon.

Caçapava do Sul (Passo Feio and Picada dos Tocos) and Lavra do Sul (Três Estradas) areas (Rocha et al. 2013, Toniolo et al. 2013, Maciel 2016, Cerva-Alves et al. 2017), all in the Rio Grande do Sul State. Because the last three intrusions are believed to be of Proterozoic age, with U-Pb zircon data indicating a ca. value of $603.2 \pm 4.5 \mathrm{Ma}$ for the Picada dos Tocos beforsite (Cerva-Alves et al. 2017), they are excluded of this study. Other important carbonatitic occurrences are the Amambay (Cerro Chiriguelo, Cerro Sarambí; Comin-Chiaramonti et al. 2014) and Velasco (Cerro Manomó; Comin-Chiaramonti et al. 2011) regions in Paraguay and Bolivia, respectively. Figure 1 shows the distribution of alkaline and alkaline-carbonatite occurrences in the three countries.

The present paper reviews general aspects of carbonatite bodies represented by not only well-defined structures and a variety of dikes and veins, but also small aggregates (ocelli) in coarse and fine-grained alkaline silicate rocks.

\section{GEOLOGICAL SETTING}

The most remarkable alkaline-carbonatite complexes of the southeastern Brazilian Platform usually show intrusive/subintrusive, subcircular or oval-shaped structures that are clearly discerned in aerial photographs and are indicative of high emplacement energy. In general, carbonatites are found chiefly as stocks, plugs, dikes, dike swarms, and veins, forming occasionally complex systems (stockworks) as in Barra do Itapirapuã in the Ribeira Valley (Ruberti et al. 2002, 2008), where distinct events may be recognized from a network of multiple intrusions. Dikes and veins constitute single bodies or complex systems that cut associated alkaline silicate rocks or penetrate country rocks. Occasionally, dikes conform to a radial or ring-like distribution. Sometimes, they correspond to more than one rock generation phase, like in Barra do Itapirapuã (Ruberti et al. 2002, 2008), Juquiá (Walter et al. 1995) and Cerro Chiriguelo (Censi et al. 1989) districts, for example. Carbonatites and their associated alkaline rocks are commonly emplaced into Precambrian groups (e.g., Açungui, Araxá, Canastra, etc.) and have quartzites, schists, granites and gneisses as their main country rocks. However, some complexes also intrude sedimentary rocks of different types and ages, the regional rocks consisting, in a few cases (e.g., Lages and Santo Antônio da Barra), of tholeiitic basalts of the Paraná Basin.

In most cases, the emplacement of alkaline-carbonatite complexes is controlled by ancient tectonic features that were reactivated in Mesozoic times, related mainly to regional structures such as arches, lineaments and rifts. These tectonic alignments have been active since Lower Cretaceous, as suggested by the distribution of earthquakes in southern Brazil (Berrocal \& Fernandes 1996). The most prominent tectonic lineaments are represented by deep, NW-trending parallel fractures clearly associated with arch structures (Almeida 1971) and, apparently, in some cases, by old NE-trending fault zones as in Itanhaém (Coutinho \& Ens 1992) and Cerro Manomó (Comin-Chiaramonti et al. 2005d). In the Ribeira Valley, emplacement was tectonically related to the Ponta Grossa Arch (Algarte 1972), a NW-trending uplift structure active since Paleozoic times that consists of four different lineaments (Guapiara, São JerônimoCuriúva, Rio Alonso and Piqueri; Almeida 1983). The 
major Jacupiranga and Juquiá complexes are related to the Guapiara Lineament, whereas Barra do Itapirapuá, Itapirapuã and Mato Preto ones associate with the São Jerônimo-Curiúva Lineament. Other occurrences in the region (Ipanema, Itanhaém and Piedade) are linked to the Piedade Lineament, a parallel structural feature lying to the south (Riccomini et al. 2005). The Alto Paranaíba complexes in Minas Gerais (Araxá, Cataláo I and II, Salitre, Serra Negra, and Tapira) follow a NW-trending linear structure that borders the São Francisco Craton, as indicated by aeromagnetic surveys, corresponding to a well-marked regional high, the Alto Paranaíba Uplift (Hasui et al. 1975). In the state of Goiás, occurrences (Caiapó, Morro do Engenho and Santo Antônio da Barra) are controlled by a pronounced NW-trending alignment that shows rift tectonics characteristics (Almeida 1983). Considering the distribution of alkaline bodies in both areas along NW-trending crustal discontinuities, that extend for considerable distances, and the nature of the magmatism, Riccomini et al. (2005) postulated that deep lithospheric faults played a major role in the tectonic control of these carbonatitic occurrences. According to these authors, the emplacement of carbonatites in the state of Santa Catarina is still a matter of debate: Lages appears to have been subject to NW-trending faults, whereas Anitápolis does not show a clear structural control. In the specific case of Anitápolis, Melcher and Coutinho (1966) pointed out the influence of N-S-trending faults. Comin-Chiaramonti et al. (2005c) proposed the Uruguay Lineament to have controlled the emplacement of both complexes. The recently described occurrences in Rio Grande do Sul (Jocas Tavares and Porteira) are structurally controlled by NE-trending faults related to the Ibaré Lineament (Costa et al. 1995). In Amambay, northeastern Paraguay, the Cerro Chiriguelo and Cerro Sarambí complexes are tectonically related to the NE-trending Ponta Porã Arch (Livieres \& Quade 1987, Comin-Chiaramonti et al. 1999). There, more intense magnetic anomalies at the southwestern end of the arch seem to support such a hypothesis (Velázquez et al. 1998). Comin-Chiaramonti et al. (2005c) also recall that both these Paraguayan complexes and the Valle-mí dikes are mainly found along the Piquiri Lineament. Sapucai in central-eastern Paraguay is located within the domains of the Asunción Rift and its associated faults.

Deep and extensive weathering processes are characteristics of alkaline-carbonatite occurrences, rocks being usually covered by laterite layers that can reach $300 \mathrm{~m}$ thick. Soils originate mainly from alteration of cumulate (ultramafic) rocks and from dissolution of carbonates of carbonatites. As a result, large supergenic and residual deposits of apatite, pyrochlore, vermiculite, anatase and REE carbonates and phosphates can be present (Biondi 2005). Fresh rocks are usually scarce or even inexistent at surface, and samples for petrological studies are obtained mostly from drill cores. Jacupiranga is the only exception, presently mined for phosphate (Morro da Mina) with good local exposures that allow for sampling of fresh rock.

\section{PETROGRAPHIC AND MINERALOGICAL CONSIDERATIONS}

The carbonatites are characterized by a large variation in grain-size and texture, that grades from equi- to inequigranular and hypidiomorphic to allotriomorphic or even seriate. Other common features include structural flow with alignment of elongated crystals (e.g. apatite), presence of brecciated and xenolithic material, and typical banding from differential concentration of minerals, particularly apatite, phlogopite, olivine and magnetite, as well evidenced in Jacupiranga carbonatites (Melcher 1966, Morbidelli et al. 1986, Chmyz et al. 2017).

The carbonatites are associated (or spatially rather than genetically associated, as postulated by Gittins \& Harmer 2003) with silicate rock types of varied composition, mainly cumulates of different petrographic and compositional characteristics. They are found in close contact with ultrabasic-ultramafic lithologies having dunites, peridotites and pyroxenites as their main representative variants (Tab. 1). These rocks are abundant and well-exposed at surface in the Jacupiranga (Melcher 1966, German et al. 1987) and Juquiá (Born 1971, Beccaluva et al. 1992) complexes, but are also present in a large number of occurrences. Other cumulates associated with carbonatites are glimmerites, especially in Ipanema (Guarino et al. 2012) and Cataláo (Machado Jr. 1991, Carvalho \& Bressan 1997, Cordeiro et al. 2010); bebedourites in Alto Paranaíba complexes, notably in Salitre (Barbosa 2009, Barbosa et al. 2012a, 2012b) and Tapira (Brod et al. 2013); phoscorites in Anitápolis (Furtado et al. 1986, Scheibe et al. 2005), Ipanema (Guarino et al. 2012) and several bodies in Alto Paranaíba (Cordeiro et al. 2010, Guarino et al. 2017); kamafugites, kimberlites, lamproites and picrites. All these rock types are practically restricted to occurrences in Minas Gerais and Goiás (Danni 1994, Meyer et al. 1994, Gibson et al. 1995a, 1995b, Brod et al. 2000, 2005, Sgarbi et al. 2000, JunqueiraBrod et al. 2000, 2002, Melluso et al. 2008, Guarino et al. 2013, 2017), except for the presence of kimberlites in Lages (Scheibe et al. 2005) and kimberlites and 

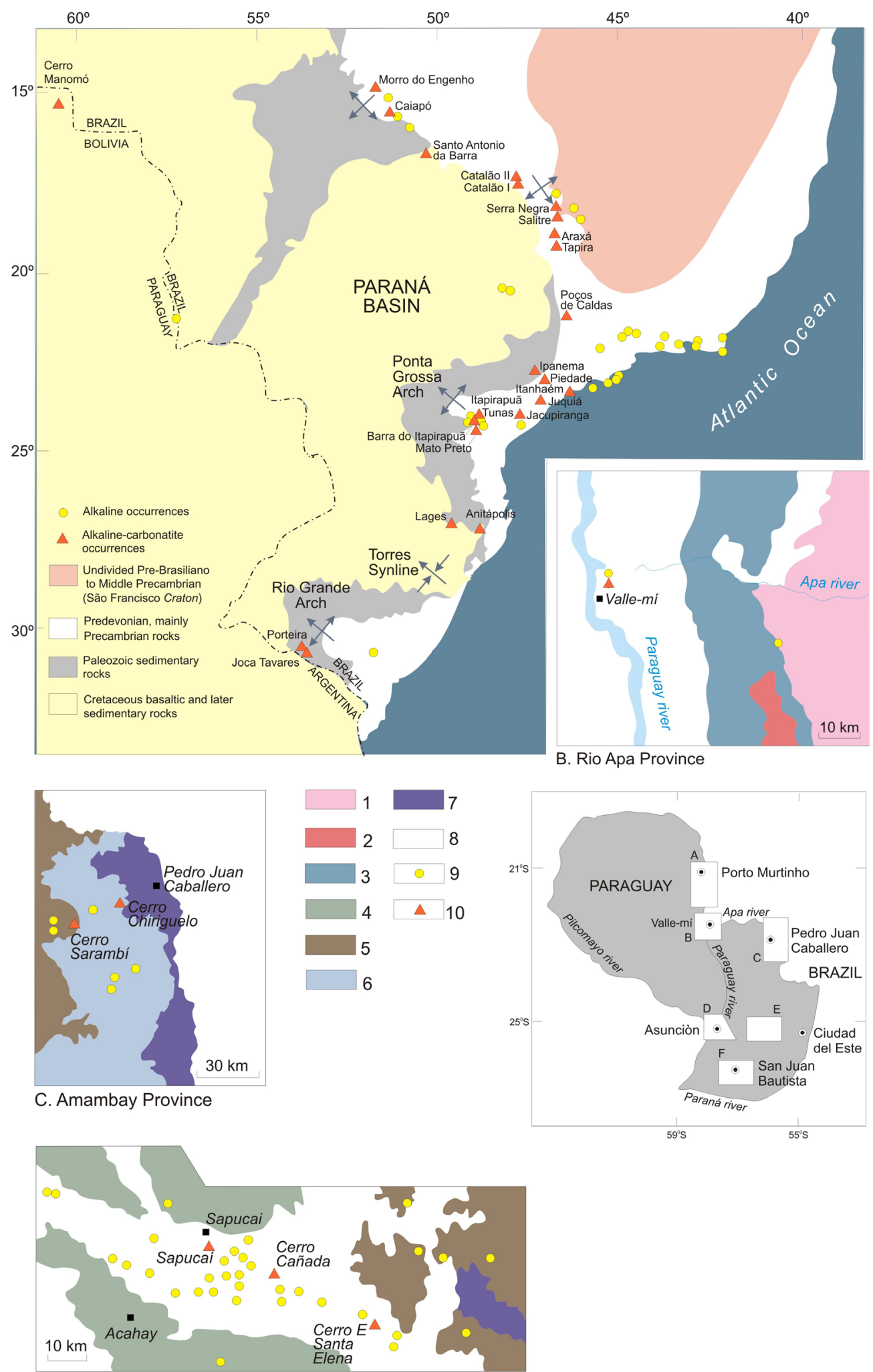

E. Central Province

Figure 1. Schematic maps showing the distribution of alkaline and alkaline-carbonatite occurrences in Brazil (after Ulbrich \& Gomes, 1981, modified) and Paraguay (after Gomes et al. 2013, simplified). Also, indicated is the location of the Cerro Manomó in Bolivia. Captions for the Paraguayan rocks: (1) Lower Precambrian, Rio Apa Complex; (2) Upper Precambrian, Alumiador Intrusive Suite; (3) Cambrian Sediments, Itapucumi Group; (4) Silurian Sediments, Caacupé Group; (5) Carboniferous Sediments, Cerro Corá Group; (6) Triassic Sediments, Misiones Formation; (7) Cretaceous Tholeiitic Magmatism, Alto Paraná Formation (Serra Geral Formation in Brazil); (8) Tertiary and Quaternary Sediments; (9) Alkaline occurrences; (10) Alkaline-carbonatite occurrences. 
lamproites in Rio Grande do Sul (Philipp et al. 2005). Monomineralic cumulatic rocks (apatitites, magnetitites, phlogopitites) were described in a few complexes (e.g., Anitápolis, Ipanema and Cataláo) as small segregations forming decimetric to metric irregular bands.

Association of carbonatites and alkaline gabbros of the melteiigite-ijolite-urtite series is quite frequent. It chiefly characterizes the alkaline-carbonatites of southeastern Brazil, especially in the Ribeira Valley, being particularly frequent in Jacupiranga and Juquiá and of subordinate presence in other districts (Ruberti et al. 2005, Gomes et al. 2011a). Association with lithologies of syenitic composition represented by coarse-grained (nepheline syenites, syenites) and fine-grained (phonolites, trachytes) rock types (Beccaluva et al. 1992, Ruberti et al. 2002) is also frequent. The presence of fenites, mostly of syenitic composition, is notable. Syenodioritic and dioritic fenites are scarce. Fenites are described in many carbonatitic bodies as forming irregular masses in the inner parts of the alkaline intrusions or being concentrated along their borders. Fenitization processes are occasionally responsible for aureoles in country rock that can reach tens of meters wide (e.g., $2.5 \mathrm{~km}$ in Araxá, Rodrigues \& Lima 1984; 2.0 $\mathrm{km}$ in Jacupiranga, Gaspar 1989). Fenites do not usually constitute individual mappable units. They are interpreted as metasomatic bodies originated by either magmatic fluids enriched in $\mathrm{Na}$ and/or $\mathrm{K}$ and $\mathrm{F}$ from carbonatitic or alkaline silicatic magmas acting on the associated alkaline rocks and country rocks. Such processes can be of sodic or potassic nature, as suggested by changes in the chemical composition and texture of the rocks and by mineralogical evidences, notably the presence of sodic pyroxene and/or amphibole in the first case, and the appearance of alkali potassic feldspar in the second case (Le Bas 2008). Evidence of fenitization has been reported for a large numbers of alkaline-carbonatite complexes, especially where carbonatites are in direct contact with ultrabasic rocks (e.g., Morbidelli et al. 1986, Guarino et al. 2012). Jacupiranga is the best example of such an association, with pyroxenites (jacupirangites) and carbonatites forming reaction bands from fenitization of older ultrabasic rocks by alkali-enriched metasomatic fluids derived from carbonatite magma. This type of reaction bands was investigated in detail by Morbidelli et al. (1986), who distinguished among concentric, centimeter-to-decimeter layers consisting of alternating carbonate and silicate material. Amphibolitization and phlogopitization of the pyroxenitic protolith by alkali-enriched fluids associated with carbonatitic magmas seem to be a constant feature in almost all Brazilian and Paraguayan carbonatite complexes (Haggerty \& Mariano 1983, Gomes et al. 1990).
Petrographic associations allow the major alkaline-carbonatite complexes to be identified as primary or magmatic carbonatites, as defined by Mitchell (2005) and Woolley and Kjarsgaard (2008). Yet, they allow most carbonatites to be included in at least two different clans that conform in general terms the geographic distribution areas of the occurrences.

The nephelinite-clan carbonatites (Mitchell 2005) or carbonatite occurrences with melteigite-ijolite-urtite (no nephelinite extrusive rocks, Woolley \& Kjarsgaard 2008) are a classical association, ijolite being the predominant rock type. They represent about $20 \%$ of the magmatic carbonatite occurrences known to the latter authors worldwide. Ultramafic bodies (pyroxenites or olivinites or both), interpreted as cumulates, correspond to $60 \%$ of the occurrences, whereas nepheline syenites and syenites, along with rocks of the melteigite-ijolite-urtite series, are present in $84 \%$ of the cases. Considering the occurrences reviewed in the present study, this is the most abundant association, being represented mainly by the Lower Cretaceous complexes of the Ribeira Valley (Ipanema, Itapirapuã, Jacupiranga, Juquiá), Santa Catarina (Anitápolis) and Paraguay (Cerro Sarambí) and the Upper Cretaceous intrusions of Mato Preto, also in the Ribeira Valley and, apparently, Caiapó and Morro do Engenho in Goiás.

Melilite-clan carbonatites (Mitchell 2005) and carbonatite occurrences with melilite-bearing (melilitolite) intrusive rocks (Woolley \& Kjarsgaard 2008) associations are not very common, even at global scale. Only 13 (3\%) of a total 403 published occurrences are listed by the latter authors, some of them bearing rocks of the melteigite-ijolite-urtite series, nepheline syenites or syenites (or both) and, frequently, phoscorites. Mitchell (2005) included the Upper Cretaceous Alto Paranaíba complexes of Araxá, Cataláo and Tapira in this clan, stressing that Minas Gerais is one of the three regions in the world characterized by extensive development of melilitolite-bearing complexes. The author also emphasized the paucity of nepheline syenite and ijolite-urtite as a representative feature that distinguishes melilitolite complexes from plutonic rocks of the nephelinite clan. Apparently, only the Tapira occurrence is known to include melilite-bearing rocks. Guimaráes et al. (1980) reported the presence of a dike of uncompahgrite (an ultramelilitolite according to Dunworth $\&$ Bell 1998) in which the modal content of the mineral reaches up to $63 \%$. The inclusion of Tapira in this clan was also confirmed by Woolley and Kjarsgaard (2008). However, the other Alto Paranaíba complexes were included in a new clan, the carbonatite occurrences with only olivinite and pyroxenite as ultramafic rocks ( \pm syenite). This clan is characterized by a broad spectrum of ultramafic rocks including olivinites (dunites), peridotites, pyroxenites, amphibolites and glimmerites among the carbonatite complexes. Additional 
rock types are phoscorites, nepheline syenites and syenites (or both). In some localities, carbonatites form km-scale diameter ore-hosting bodies with $\mathrm{Nb}$ (pyrochlore), phosphate and vermiculite. Rocks of the melteigite-ijolite-urtite series are missing. Guarino et al. (2017) emphasized the close relationship of Alto Paranaíba carbonatites and phlogopite picrites and ultramafic lamprophyres.

Although not mentioned by either Mitchell (2005) or Woolley and Kjarsgaard (2008), melilite-bearing rocks are also found in an Upper Cretaceous alkaline-carbonatite occurrence in Lages, State of Santa Catarina (Traversa et al. 1994, 1996, Gibson et al. 1999). Their occurrence is of very complex composition, consisting of large amounts of syenitic rocks (predominantly phonolites and peralkaline phonolites), carbonatites, ultrabasic types that occur mainly as dikes, and kimberlites. Outcrops of olivine melilitites are described in various places in Lages, Cerro Alto de Cima, a semiring, 50 $m$ wide dike being the most significant body (Scheibe 1986).

More recently, Beccaluva et al. (2017) noticed the presence of melilite with modal content higher than $10 \%$ in ijolitic rocks of the Jacupiranga carbonatites.

Additionally, the overall petrographic association allows to distinguish a new group of carbonatites, the hydrothermal ones (also referred to as carbothermals by Mitchell 2005; or carbohydrothermals by Woolley \& Kjarsgaard 2008). These latter authors define carbohydrothermal carbonatites as formed by precipitation at subsolidus temperatures, from a mixed $\mathrm{CO}_{2}-\mathrm{H}_{2} \mathrm{O}$ fluid that can be either $\mathrm{CO}_{2}$-rich (i.e., carbothermal), or $\mathrm{H}_{2} \mathrm{O}$-rich (i.e., hydrothermal). Mitchell (2005) added variable proportions of $F$ to the composition of the low-temperature fluids. A statistical study performed by Woolley and Kjarsgaard (2008) indicated that carbohydrothermal carbonatites amounted to 74 out of the 477 occurrences (magmatic carbonatites included) in the world, 54 of them being predominantly associated with intrusive alkali silicate rocks. Their research also made evident that syenitic rocks (feldspathoidal syenites, syenites and quartz syenites) constitute the dominant silicate rock in this association. Also according to Woolley and Kjarsgaard (2008), these occurrences typically consist of calcite \pm barite \pm fluorite \pm quartz \pm sulfides \pm K-feldspar \pm zeolites. However, the hydrothermal stages can also have involved enrichment in elements such as Th, REE and F, as reflected in the mineralogical assemblage, that bears REE fluorocarbonates, fluorite and other fluoride phases. Based on chemical and mineralogical evidence, notably the presence of rare accessory phases like ancylite, bastnäesite, synchysite, parisite, etc., Barra do Itapirapuã (Ruberti et al. 2002, 2008), Cerro Chiriguelo (Haggerty \& Mariano 1983, Censi et al. 1989) and Cerro Manomó (Fletcher et al. 1981, Comin-Chiaramonti et al. 2005d, 2011) complexes fall within the hydrothermal group.
No data is presently available on the Piedade (SP), Jocas Tavares (RS) and Porteira (RS) carbonatites, but, considering the occurrence of alkaline rocks in Rio Grande do Sul, represented by the phonolitic suite of Piratini (Barbieri et al. 1987), it is possible that both bodies correlate with the aforementioned volcanism event. Woolley and Kjarsgaard (2008) described the occurrence of carbonatite with only phonolite or feldspathoidal syenite, without any ultramafic cumulates or members of the melteigite-ijolite-urtite series or melilite-bearing rocks. This association is considered to be the third most significant one, with carbonatite intrusions forming small dikes into larger bodies.

Other carbonatitic occurrences are represented by small dikes in Itanhaém (Coutinho \& Ens 1992) and in an island on the coast of the State of São Paulo (Ilhas, Coutinho 2008); dikes and ultramafic silico-carbonatitic plugs and carbonatitic fragments within volcanoclastic deposits in the Poços de Caldas alkaline complex (Ulbrich et al. 2002, 2005, Vlach et al. 2003, Alves 2003); and as minor aggregates (ocelli) in association with fine-grained (Valle-mí) and coarse-grained (Cerro Cañada and Cerro E Santa Elena) silicate alkaline rocks in Paraguay (Castorina et al. 1997, Comin-Chiaramonti et al. 2007a, Gomes \& Comin-Chiaramonti 2017).

Carbonatites are predominantly calcic (sövites-alvikites) and, even in more magnesian (beforsites) intrusions (e.g., Araxá, Barra do Itapirapuã, Juquiá, etc.), calcite is an important constituent. A more iron-rich composition with ankerite as the chief mineral form is present in Lages and Cerro Manomó, for example (Comin-Chiaramonti et al. 2002, 2011). The three primary end-member minerals are not usually found in the same complex, Barra do Itapirapua and Juquiá being the most noticeable exceptions, with such phases present in different stages of intrusion. More commonly, carbonate minerals exhibit a complex and varied chemical composition, due mainly to post-magmatic changes induced by hydrothermal and deuteric-groundwater processes, as described by Comin-Chiaramonti et al. (2007a) in many occurrences of Lower Cretaceous (e.g., Barra do Itapirapuá, Cerro Chiriguelo) and Upper Cretaceous (e.g., Lages, Mato Preto). A secondary, hydrothermal mineralogical assemblage is the main characteristic of some complexes bearing heterogeneous and complex chemical composition phases enriched in $\mathrm{Nb}, \mathrm{Ti}, \mathrm{Zr}$, Th, U, F, Ba, and REE. Araxá and Barra do Itapirapuã are good examples of a mineral assemblage consisting of REE-bearing carbonates, fluorocarbonates and phosphates, which was intensively investigated by Traversa et al. (2001) and Ruberti et al. (2008), respectively. Additional mineral information is also found in the studies by Fletcher et al. (1981, on Cerro Manomó), Haggerty and Mariano (1983, on Salitre, Cerro Chiriguelo and Cerro Sarambí) and Menezes Jr. and Martins (1984, on Jacupiranga). Table 7.1 
of Gomes and Comin-Chiaramonti (2017) compiles a great number of less common and even exotic minerals related to alkaline-carbonatite complexes, including sorosilicates (lamprophyllite, rosenbuschite, Sr-chevkinite), cyclosilicates (eudialyte, wadeite), inosilicates (pectolite, serandite, wollastonite), phyllosilicates (neptunite), oxides and hydroxides (baddeleyte, loparite, menezesite, perouskite, pyrochlore, zirconolite), carbonates (alstonite, ancylite, bastnäesite, breunnerite, burbankite, cordyllite, magnesite, norsethite, olekminskite, parisite, remondite, shortite, strontianite, synchysite, witherite), and phosphates (britholite, galgenbergite, gorceixite, monazite). Although not cited in Table 7.1, the following should be also mentioned: carbonates (ankerite, kutnehorite, rodochrosite, siderite), fluorides (fuorite), oxides (calzirtite, geikielite, uranpyrochlore), phosphates (dahlite), sulphates (barite, celestine), and sulfides (chalcopyrite, galena, phyrotite, pyrite, sphalerite).

\section{AGES}

Except for a small number of occurrences such as Barra do Itapirapuã, Jacupiranga and Poços de Caldas (Ruberti et al. 1997, Chmyz et al. 2017, Vlach et al. 2003, respectively), whose ages were determined directly from carbonatites and their mineral constituents, most available data resulted from analysis of associated silicate alkaline rocks (whole-rock and mineral concentrates of different minerals). Data for all presently known alkaline-carbonatite occurrences indicates that these rocks are of Cretaceous age, with two clearly distinguished formation intervals, 120-140 Ma and 70-90 Ma, Lower Cretaceous and Upper Cretaceous (Ulbrich \& Gomes 1981, Rodrigues \& Lima 1984, Berbert 1984, Gomes et al. 1990, Gibson et al. 1995a, Ruberti et al. 2005, Comin-Chiaramonti et al. 2007a, 2007b, Gomes et al. 2011a, 2011b, 2013, Gomes \& Comin-Chiaramonti 2017). Preferred ages for the occurrences are shown in Figure 2.

\section{Lower Cretaceous}

Although some results are yet to be confirmed by new analytical methods, this interval is apparently represented by three distinct generation episodes. The oldest age of $\sim 139$ Ma is suggested for the Amambay (Cerro Chiriguelo and Cerro Sarambí), Rio Apa (Valle-mí) occurrences in northern Paraguay and Cerro Manomó in southeastern Bolivia. An average approximately $130 \mathrm{Ma}$ age characterizes the Ribeira Valley complexes (Barra do Itapirapuã, Ipanema, Itanhaém, Jacupiranga, Juquiá and Piedade) in southeastern Brazil and also Anitápolis to the south, in the State of Santa Catarina. Carbonatite flows cropping out nearby the village of Sapucai and ijolitic rocks of Cerro Cañada and Cerro E Santa Elena, all in central-eastern Paraguay, are probably related to the same magmatic event. The Itapirapuã massif, also in the Ribeira Valley, seems to represent the youngest Lower Cretaceous episode, with ages in the 100-110 Ma range, as suggested by old $\mathrm{K}-\mathrm{Ar}$ results (Gomes \& Cordani 1965) confirmed by recent Ar-Ar and U-Pb SHRIMP determinations (Gomes et al. 2018).

\section{Upper Cretaceous}

The Alto Paranaíba (Araxá, Catalão I and II, Salitre, Serra Negra and Tapira) and Goiás (Santo Antônio da Barra) complexes in central-western Brazil, together with Mato Preto and Lages complexes in the south, have ages that fall within the 70-90 Ma interval. The Joca Tavares and Porteira bodies in the State of Rio Grande do Sul probably belong to the same interval.

It is also important to notice that three of the above ages fit the chronogroups of $133 \mathrm{Ma}, 108 \mathrm{Ma}$ and $84 \mathrm{Ma}$ proposed by Ulbrich et al. (1991) to define peaks of alkaline magmatism along the borders of the Paraná Basin. These chronogroups are believed to represent different phases of evolution of the basaltic and alkaline magmatism in the South Atlantic Plate. They stress the coherent relationship of this volcano-tectonic cycle to important changes in the position of rotation poles and spreading rates of the South American and African plates (Herz 1977, Sadowski 1987).

\section{GEOCHEMISTRY}

\section{Major elements}

Chemical data indicates that the carbonatites range in composition from calciocarbonatites to magnesiocarbonatites to ferrocarbonatites. However, association of these different petrographic types in a same complex is rare (e.g., Araxá, Barra do Itapirapuá, Juquiá). Plottings of whole-rock chemistry data in $\mathrm{CaO}-\mathrm{MgO}-(\mathrm{FeO}+\mathrm{MnO})$ classification diagrams (Woolley \& Kempe 1989) are discussed in various papers (e.g., Comin-Chiaramonti et al. 2001, 2002, 2005c, 2007a, Gomide et al. 2016). They usually stress the large chemical variation of carbonatites, analyses covering the three, $\mathrm{Ca}$, $\mathrm{Mg}$ and $\mathrm{Fe}$ compositional fields. Calciocarbonatites are the most abundant types, followed by magnesiocarbonatites. Calciocarbonatites constitute the main lithology in Anitápolis, Cerro Chiriguelo, Ipanema, Itapirapuá, for instance, whereas magnesiocarbonatites predominate in complexes like Araxá, Barra do Itapirapuã, and Juquiá. Ferrocarbonatites are of subordinate occurrence, being more significant only in Lages (Scheibe et al. 2005) and Cerro Manomó (CominChiaramonti et al. 2002, 2011, respectively). The Bolivian Cerro Manomó complex represents the most striking occurrence of ferrocarbonatites, with $40.5 \mathrm{wt} \%$ of $\mathrm{FeO}, 7.7 \mathrm{wt} \%$ 
of $\mathrm{CaO}, 0.34 \mathrm{wt} \%$ of $\mathrm{MgO}$ and $7.1 \mathrm{wt} \%$ of $\mathrm{MnO}$ (CominChiaramonti et al. 2011). However, it is important to consider that in some complexes like Barra do Itapirapuã, Jacupiranga and Juquiá, the evolution of carbonatite magmas resulted in rocks of wide variation in chemical composition representing different stages of intrusion. Thus, early stage carbonatites of the Jacupiranga and Alto Paranaíba complexes tend to show a more calcic composition, that evolved to more magnesian in latter stages of crystallization (Gomide et al. 2016). This calciocarbonatites $\rightarrow$ magnesiocarbonatites evolution trend, reaching up to ferrocarbonatites in a few cases, has been described in Barra do Itapirapuã (Ruberti et al. 2002), Cerro Chiriguelo (Censi et al. 1989) and Juquiá (Walter et al. 1995) complexes. In some occurrences (e.g., Mato Preto, Santo Antônio da Barra, etc.), the carbonatitic association also includes silicocarbonatites, carbonatites with $>20 \% \mathrm{SiO}_{2}$ occurring mostly as dikes.

The Lower Cretaceous carbonatites of southern Brazil seem to be chemically related to a potassic magmatism of plagioleucitic composition in Foley's (1992) classification (Comin-Chiaramonti \& Gomes 1996b), chiefly represented by evolved rock types of syenitic filiation. On the other

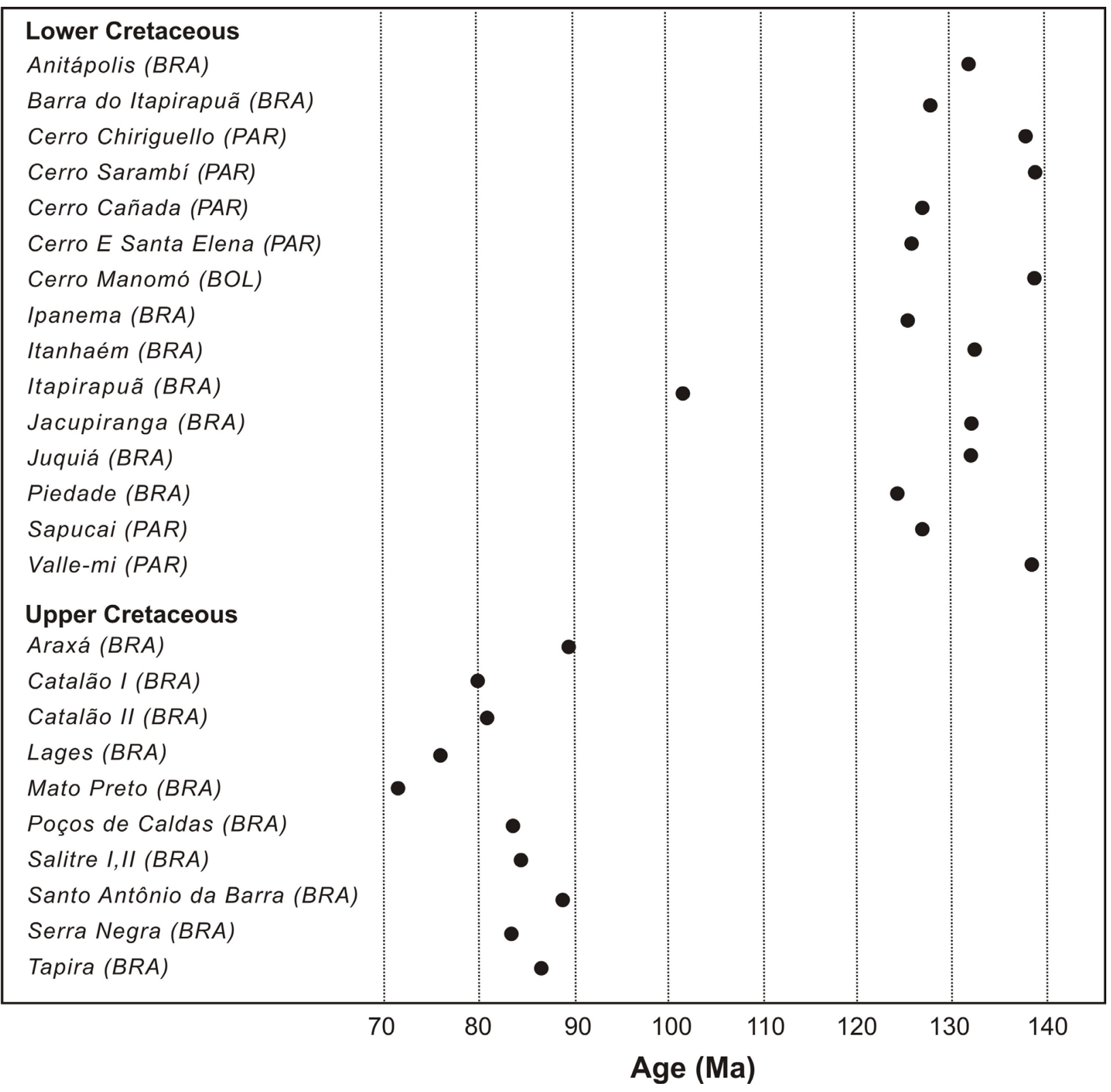

Figure 2. Reference age diagram for carbonatite occurrences in the southern Brazilian Platform. Data source follows references listed in Table 1. 
hand, the Upper Cretaceous carbonatites of central-western Brazil are characterized by ultrapotassic-kamafugitic associations (Junqueira-Brod et al. 2002, Guarino et al. 2017). Usually, also included in the Lower and Upper Cretaceous occurrences are less evolved lithologies of gabbroic-basaltic affinity and cumulates of diverse nature (e.g., dunites, pyroxenites, phoscorites).

\section{Trace and rare earth elements}

Incompatible elements (IE) diagrams normalized to primitive mantle concentration (Sun \& McDonough 1989) for Brazilian Lower Cretaceous carbonatites (Anitápolis, Barra do Itapirapuá, Jacupiranga, Juquiá) and Paraguay (Cerro Chiriguelo, Cerro Sarambí, Sapucai, Valle-mí) and for Upper Cretaceous Brazilian complexes (Alto Paranaíba, Lages, Mato Preto) were compiled in review papers by CominChiaramonti et al. (2005c, 2007a). Additional multielement diagrams are also found for other areas: the Ponta Grossa Arch (Gomes et al. 2011a, Azzone et al. 2013, Beccaluva et al. 2017, Chmyz et al. 2017), Amambay (Gomes et al. 2011b, Comin-Chiaramonti et al. 2014), and the Alto Paranaíba province (Gomide et al. 2016).

For any given incompatible element, there is a large variation in normalized values from one carbonatite complex to another. Scatters for the different carbonatites seem to reflect, to some extent, the variable distribution and the concentration of phases, IE occurring mainly as accessory minerals such as phosphates (e.g., apatite and monazite: rare earth elements - REE), oxides (e.g, pyrochlore: $\mathrm{Nb}$, Th, U; calzirtite: $\mathrm{Nb}, \mathrm{Zr}$; zirconolite: $\mathrm{Ti}, \mathrm{Nb}, \mathrm{Zr}$; loparite: $\mathrm{Ti}, \mathrm{Nb}, \mathrm{REE}$ ) and REE-carbonates and fluorocarbonates (e.g., ancylite, bastnäesite, burbankite, parisite, synchysite). In comparison to associated silicate alkaline rocks, the carbonatites follow a general tendency to higher abundances in practically all of the incompatible trace elements. Even considering variable composition and stage of intrusion, they are usually characterized by the presence of negative anomalies for Rb, K, P, Hf-Zr and Ti and positive spikes for Ba, Th-U and $\mathrm{La}-\mathrm{Ce}$. The behavior of Nb-Ta and $\mathrm{Sr}$ appears to be less regular, but pointing mostly to positive anomalies. Although based only on little data available (e.g., Anitápolis, Lages, Mato Preto, cf. Gibson et al. 1999, Comin-Chiaramonti et al. 2005c, 2007a), no significant difference is noticed in the chemical behavior of IE in early and late carbonatites of a same complex, except for a clear tendency of the latter rocks to be more enriched in all the elements.

REE display remarkable scatters even within a single complex. This is particularly evident for samples from areas that involve different stages of formation, i.e., magmatic, late-magmatic or hydrothermal conditions. Similar to the IE, scatters are mainly attributed to the presence of accessory minerals such as apatite, REE fluorocarbonates, fluorite and barite. REE fluorocarbonates are relatively abundant in late stage carbonatites (e.g., Barra do Itapirapuã, Cerro Manomó). Chondrite-normalized (Thompson 1982, Boynton 1984, McDonough \& Sun 1995) REE distribution diagrams for various carbonatite complexes are discussed in several papers (e.g., Comin-Chiaramonti et al. 2005c, 2007a, 2014, Gomes et al. 2011a, 2011b, Azzone et al. 2013, Gomide et al. 2016, Beccaluva et al. 2017, Chmyz et al. 2017). Patterns are in general marked by high REE concentration and variable LREE/ HREE fractionation degrees. A strong increase from $\mathrm{Lu}$ to La is observed in Cerro Chiriguelo, Jacupiranga, Lages (both early and late carbonatites) and Mato Preto complexes, and also Alto Paranaíba occurrences that characterizes different stages of fractional crystallization (C1 to C5, cf. Gomide et al. 2016). Flat REE or patterns with a smooth decrease from La to Lu are characteristic of Anitápolis, Barra do Itapirapuã (late calciocarbonatites), Ipanema, Jacupiranga (calciocarbonatites) and Juquiá (magnesio- and calciocarbonatites) rocks. In these occurrences, the REE distribution seems to be related to the apatite composition. Concave patterns with a HREE plateau and a steady increase from Dy to LREE are typical of Valle-mí and Barra do Itapirapuã carbonatitic rocks. Ferrocarbonatites are generally more enriched than calcio- and magnesiocarbonatites, mainly as evidenced in Lages. Comin-Chiaramonti et al. (2007a) gave especial attention to the stockwork of Barra do Itapirapuá, that includes four generations of carbonatite dikes of similar, parallel and slightly enriched LREE pattern. As a result from the presence of REE fluorocarbonate minerals, the dikes more intensely subject to hydrothermal alteration show higher LREE concentrations (Andrade 1998).

\section{$\mathrm{C}$ and $\mathrm{O}$ isotopes}

The behavior of carbon and oxygen isotopes derived mainly from carbonates of Brazilian and Paraguayan carbonatitic rocks has been discussed in detail by many authors over the last decades (e.g., Nelson et al. 1988, Censi et al. 1989, Santos et al. 1990, Santos \& Clayton 1995, Huang et al. 1995, Toyoda et al. 1994, Walter et al. 1995, Castorina et al. 1996, 1997, Speziale et al. 1997, Andrade et al. 1999, Comin-Chiaramonti et al. 2001, 2002, 2005b, 2005c, 2007a, Ruberti et al. 2002, Gomide et al. 2013, 2016, Gomes \& Comin-Chiaramonti 2017). In general, $\delta^{18} \mathrm{O}$ data available in literature for such occurrences covers a wide interval, from about 5 to $25 \%$ (V-SMOW notation per thousand, cf. Deines 1989). For approximately 50\% of the analyses, however, results lie between 6 and $10 \%$. In contrast, $\delta^{13} \mathrm{C}$ values show a more restricted variation, with $91 \%$ of the analyses falling between $-2 \%$ and $-8 \%$ o (PDB-1 notation per thousand, cf. Deines 1989). Ranges 
of $\delta^{18} \mathrm{O}$ and $\delta^{13} \mathrm{C}$ between 6 and $10 \%$ and between -4 and $-8 \%$, respectively, correspond to the field defined by Taylor et al. (1967) and Keller and Hoefs (1995) for primary carbonatites. The plot of $\delta^{18} \mathrm{O}$ vs. $\delta^{13} \mathrm{C}$ (Fig. 3), including some Brazilian Lower Cretaceous and Upper Cretaceous and Paraguayan Lower Cretaceous carbonatite occurrences, makes evident that:

a clear primary signature of the Lower Cretaceous complexes in southeastern Brazil, as exemplified mainly by the Jacupiranga rocks plotting entirely inside the range of mantle values;

two well-distinct linear enrichment trends of heavy isotopes are present.
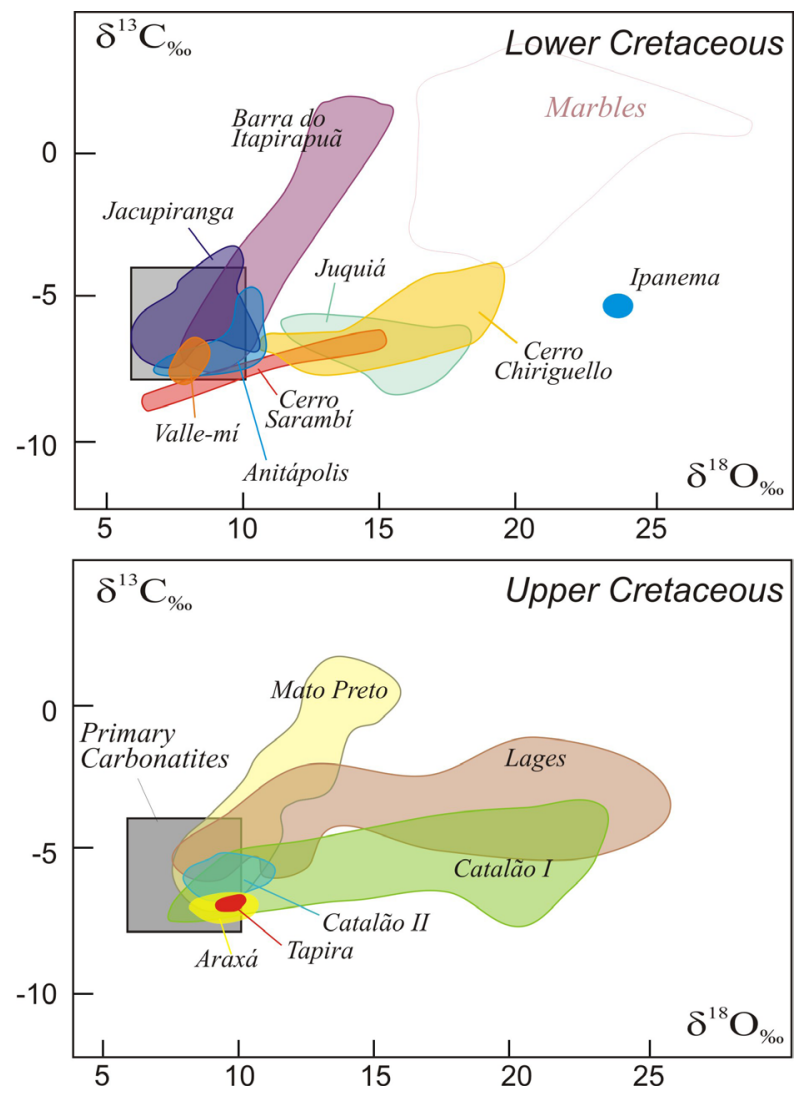

Figure 3. Fields of $\delta^{18} \mathrm{O} \%$ (V-SMOW) vs. $\delta^{13} \mathrm{C} \%$ (PDB1) for Lower Cretaceous (Jacupiranga, Juquiá, Barra do Itapirapuã, Anitápolis) and Upper Cretaceous (Araxá, Catalão I, Catalão II, Tapira, Mato Preto, Lages) carbonatites of Brazil and for Lower Cretaceous carbonatites of Eastern Paraguay (Cerro Chiriguelo, Cerro Sarambí, Valle-mí). Data sources: CominChiaramonti et al. (2005c and therein references), Cordeiro et al. (2011), Guarino et al. (2012, 2017), Gomes and Comin-Chiaramonti 2017). PC, field for primary carbonatites from Taylor et al. (1967) and Keller and Hoefs (1995); field for marbles is also from Comin-Chiaramonti et al. (2005c).
Enrichment of heavy isotopes is interpreted as resulting from mantle source heterogeneity (Nelson et al. 1988), contamination processes by country rocks, especially limestone (Santos \& Clayton 1995), or magmatic vs. hydrothermal evolution at shallow levels (Censi et al. 1989). The first trend is characterized by a shift to positive values of both $\delta^{18} \mathrm{O}$ and $\delta^{13} \mathrm{C}$ (e.g., Barra do Itapirapuá, Jacupiranga, Mato Preto), and it appears to be an extension of the Jacupiranga carbonatites, which are believed to have a primary signature (Huang et al. 1995). A similar isotopic evolution from magmatic fractionation also characterizes early stage carbonatites (C1) of the Alto Paranaíba province (Gomide et al. 2016). Other carbonatites representing intermediate (C2, $\mathrm{C} 3)$ and later (C4, C5) stages of the same region also show isotopic evolution consistent with magmatic fractionation, but with additional interaction with carbohydrotermal fluids and hydrothermal alteration. The second trend shows a $\delta^{18} \mathrm{O}$ increase for similar values of $\delta^{13} \mathrm{C}$ typical of the Juquiá, Lages, Cerro Chiriguelo and some Alto Paranaíba (e.g., Catalão I, Cataláo II, Tapira) complexes.

As stressed in literature (e.g., Deines 1989), the large variation in the content of oxygen and carbon isotopes in carbonatitic complexes results from magmatic (crystal fractionation, degassing, crustal contamination) and post-magmatic (hydrothermal) processes. Systematic investigation of carbonatites of the Paraná Basin points out that most occurrences have enriched isotopic composition and negligible or absent crustal signature, and that fractional crystallization and liquid immiscibility processes cause little effect on oxygen and carbon isotopic values (Santos \& Clayton 1995, Castorina et al. 1997, Comin-Chiaramonti et al. 2005b, Gomes \& Comin-Chiaramonti et al. 2017). Also, according to these authors, the main variations in $\delta^{18} \mathrm{O}$ and $\delta^{13} \mathrm{C}$ could be explained by isotopic exchange between these rocks and $\mathrm{H}_{2} \mathrm{O}-\mathrm{CO}_{2}$ rich fluids at different temperatures and $\mathrm{H}_{2} \mathrm{O} / \mathrm{CO}_{2}$ ratios in a hydrothermal environment (e.g., below $300^{\circ} \mathrm{C}$ for the first two authors, and in the range of $400-80^{\circ} \mathrm{C}$ and fluids with a $0.8-1 \mathrm{CO}_{2} / \mathrm{H}_{2} \mathrm{O}$ ratio for the others). The two paths of $\delta^{18} \mathrm{O}-\delta^{13} \mathrm{C}$ fractionation previously mentioned are attributed to different emplacement levels, that reflect subvolcanic and surface conditions, respectively. Weathering and groundwater fluids are locally important factors, as is meteoric water, that yielded samples strongly enriched in light carbon due to contamination by a biogenic component (Castorina et al. 1997, Comin-Chiaramonti et al. 2005b). Crustal contamination by limestone country rocks of the Açungui Group $\left(\delta^{18} \mathrm{O}=+25.0\right.$ to $+24.4 \%$ and $\delta^{13} \mathrm{C}=+3.5$ to $-8.6 \%$ ), as suggested by Santos and Clayton (1995) for Mato Preto carbonatites, does not seem necessary to explain the enrichment in both heavy oxygen and carbon isotopes of some hydrothermally altered samples of the complex, based 
on considerations by Speziale et al. (1997) and CominChiaramonti et al. (2005b). This interpretation is also supported by the initial ${ }^{87} \mathrm{Sr} /{ }^{86} \mathrm{Sr}$ and ${ }^{143} \mathrm{Nd} /{ }^{144} \mathrm{Nd}$ isotopic ratios of some selected carbonatites, that present the same values as their associated alkaline rocks (Comin-Chiaramonti et al. 2005c). Speziale et al. (1997) pointed out that, in terms of radiogenic isotopes, Barra do Itapirapuá and Mato Preto carbonatites preserve mantle source characteristics, even where original O-C isotopic signatures were in part modified by low temperature post-depositional hydrothermal fluids. A more complex situation is apparently associated with the wide $\delta^{18} \mathrm{O}$ (between 8.58 to $23.11 \%$ ) and $\delta^{13} \mathrm{C}$ (between -3.55 and $-7.88 \%$ ) values shown by Cataláo I carbonatitic rocks (Cordeiro et al. 2011, Oliveira et al. 2017). There, the original isotopic composition of carbonates was modified by at least two events of magmatic fractionation ( 1 - Rayleigh fractionation, with carbonate signatures being related to the isotopic fractionation between carbonates and other minerals as well as to the temperature and the isotopic composition of the initial melt, and 2 - degassing) and three fluid fractionation (fluid degassing, $\mathrm{H}_{2} \mathrm{O}$ percolation and $\mathrm{CO}_{2}-$ $\mathrm{H}_{2} \mathrm{O}$ fluid percolation) episodes.

Apparently, sulfur and carbon isotopic data from sulphides is only available in studies by Gomide et al. (2013, 2016) on the Alto Paranaíba complexes (Araxá, Catalão I, Catalāo II, Salitre, Serra Negra and Tapira) and Jacupiranga in the Ribeira Valley. In these occurrences, almost all carbonatite intrusions present an isotopic composition of sulfur that is compatible with values for the mantle and carbonatites around the world. Exceptions are a few Cataláo I and Tapira samples showing distinctly negative ${ }^{34} \mathrm{~S}$ values more consistent with sulfur degassing and/or hydrothermal alteration processes (Gomide et al. 2013).

Gomide et al. (2013) also noted that in Jacupiranga sulfides have relatively narrow ${ }^{34} \mathrm{~S}$ ranges and more primitive ${ }^{34} \mathrm{~S}$ values than in minerals of the Alto Paranaíba occurrences for the same rock type, which suggests that the Jacupiranga magmas are less evolved and/or that they intruded deeper levels than in the aforementioned complexes.

\section{$\mathrm{Sr}$ and $\mathrm{Nd}$ isotopes}

In Brazil and Paraguay, carbonatites are characterized by initial ${ }^{87} \mathrm{Sr} /{ }^{86} \mathrm{Sr}\left(\mathrm{Sr}_{\mathrm{i}}\right)$ and ${ }^{143} \mathrm{Nd} /{ }^{144} \mathrm{Nd}\left(\mathrm{Nd}_{\mathrm{i}}\right)$ ratios similar to those of their associated alkaline rocks, even in late stages of fluid-rock re-equilibration (i.e., hydrothermal environment), as already established by Castorina et al. (1997) and Speziale et al. (1997). However, the wide ranges of $\mathrm{Nd}_{\mathrm{i}}$ isotopes for a narrow $\mathrm{Sr}_{\mathrm{i}}$ interval reported for the Cataláo I complex by Cordeiro et al. (2011) are indicative that magmatic and/or carbohydrothermal processes were able to fractionate $\mathrm{Nd}$, leaving $\mathrm{Sr}$ isotopes unaffected. Thus, caution should be taken when analyzing carbonatites submitted to post-magmatic modifications.

In general, the $\mathrm{Sr}_{\mathrm{i}}$ and $\mathrm{Nd}_{\mathrm{i}}$ isotopic values for Brazilian Lower Cretaceous carbonatites presented by CominChiaramonti et al. (1999) range from 0.70425 to 0.70595 (mean $\mathrm{Sr}_{\mathrm{i}}=0.70527 \pm 0.00034$ ) and from 0.51213 to $0.51280\left(\right.$ mean $\left.\mathrm{Nd}_{\mathrm{i}}=0.51224 \pm 0.00011\right)$, respectively. Values of $S r_{i}=0.70538$ and $\mathrm{Nd}_{i}=0.51253$ for a sample of a carbonatite intrusion from Jacupiranga were more recently given by Beccaluva et al. (2017). Average values for Upper Cretaceous alkaline occurrences of different regions are: Alto Paranaíba, $\mathrm{Sr}_{\mathrm{i}}=0.70527 \pm 0.00036$ and $\mathrm{Nd}_{\mathrm{i}}=0.51224 \pm$ 0.00006 (Bizzi et al. 1994, Gibson et al. 1995a, 1995b, and references therein); Taiúva-Cabo Frio and Serra do Mar, $\mathrm{Sr}_{\mathrm{i}}=0.70447 \pm 0.00034$ and $\mathrm{Nd}_{\mathrm{i}}=0.51252 \pm 0.00008$ (Thompson et al. 1998); Lages, $\mathrm{Sr}_{\mathrm{i}}=0.70485 \pm 0.00053$ and $\mathrm{Nd}_{\mathrm{i}}=0.51218 \pm 0.00022$ (Traversa et al. 1996, CominChiaramonti et al. 2002). Guarino et al. (2017) postulated that the $\mathrm{Sr}-\mathrm{Nd}$ isotopic composition of the Alto Paranaíba carbonatites is markedly different from rocks of the southernmost parts of Brazil, suggesting regional-scale heterogeneity in mantle sources underneath the Brazilian Platform. In the initial $\left({ }^{87} \mathrm{Sr} /{ }^{86} \mathrm{Sr}\right)_{\mathrm{i}}$ vs. $\left({ }^{143} \mathrm{Nd} /{ }^{144} \mathrm{Nd}\right)_{I}$ correlation diagram (Fig. 4A), values for Lower and Upper Cretaceous carbonatites display the same trend defined for Lower Cretaceous tholeiitic lavas of the Paraná Basin (H-Ti and L-Ti), Upper Cretaceous volcanics of the Rio Grande Rise and Paleocene alkaline rocks of the Serra do Mar province (Comin-Chiaramonti et al. 2005c, 2007a).

Lower Cretaceous potassic alkaline rocks of Paraguay (both pre- and post- tholeiitic lavas) and associated carbonatites yield $\mathrm{Sr}_{\mathrm{i}}$ and $\mathrm{Nd}_{\mathrm{i}}$ values within $0.70612-0.70754$ and 0.51154-0.51184, respectively (Fig. 4B). These higher $\mathrm{Sr}_{\mathrm{i}}$ and lower $\mathrm{Nd}_{\mathrm{i}}$ values are distinct when compared with those relative to late Lower Cretaceous (Misiones province) and Paleocene (Asunción province, ASV) Na-alkaline rocks, i.e., $\mathrm{Sr}_{\mathrm{i}}=0.70362-0.70524$ and $\mathrm{Nd}_{\mathrm{i}}=0.51225-0.51277$. Together, they define a trend similar to the Low $\mathrm{Nd}$ array of Hart et al. (1986), i.e., Paraguayan array according to Comin-Chiaramonti et al. (1995). Figure 4B also makes evident that sodic alkaline rocks and associated xenolith plots are close to Bulk Earth (BE) values, and that the high and low $\mathrm{TiO}_{2}$ tholeiites are intermediate between $\mathrm{K}$ - and $\mathrm{Na}$-alkaline rocks.

The alkaline and alkaline-carbonatite occurrences in Figure 4 follow well-defined trends involving depleted and enriched mantle components (Gomes \& CominChiaramonti et al. 2017). The Lower Cretaceous and Upper Cretaceous Brazilian complexes range from close to $\mathrm{BE}$ to the enriched quadrant, falling within uncontaminated tholeiitic lavas of the Paraná-Angola-Namibia (Etendeka) province 
(Comin-Chiaramonti et al. 1997). On the other hand, isotopically Sr-enriched alkaline and alkaline-carbonatites of Paraguay are not easily explained by crustal contamination processes, because that would require high percentages of
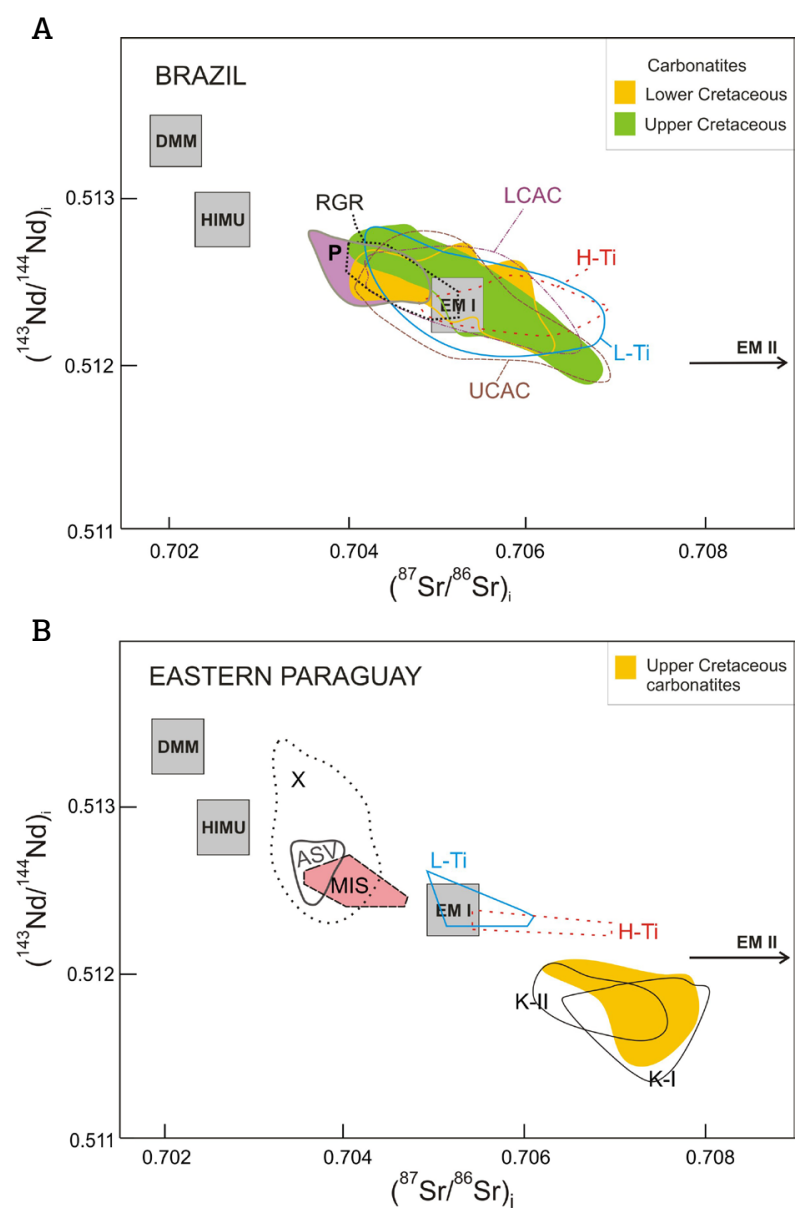

Figure 4. Correlation diagrams for ${ }^{87} \mathrm{Sr} /{ }^{86} \mathrm{Sr}(\mathrm{Sr})_{\text {i }}$ vs. ${ }^{143} \mathrm{Nd} /{ }^{144} \mathrm{Nd}(\mathrm{Nd})_{\text {i }}$ initial ratios for Brazilian and Paraguayan alkaline-carbonatites after CominChiaramonti et al. (2005c, modified). Basalts and andesi-basalts are represented by poorly crustally contaminated or uncontaminated rocks (Piccirillo \& Melfi 1988). (A) Brazil: H-Ti, L-Ti and LCAC, Lower Cretaceous high- and low- $\mathrm{TiO}_{2}$ flood tholeiites and alkaline complexes, respectively; RGR and UCAC, Upper Cretaceous Rio Grande Rise volcanic rock types and alkaline complexes, respectively; $\mathrm{P}$, Paleocene alkaline complexes in the Serra do Mar region. (B) Eastern Paraguay: K-I and K-II, Lower Cretaceous potassic alkaline complexes, pre- and post-tholeiites, respectively; $\mathrm{H}-\mathrm{Ti}$ and $\mathrm{L}-\mathrm{Ti}$ as in (A); MIS, late Lower Cretaceous sodic alkaline complexes in the Misiones province; ASV, Paleocene sodic alkaline complexes in the Asunción province and associated mantle xenoliths (X). Data sources for both diagrams are given in Comin-Chiaramonti et al. (2005c). DMM, HIMU, EM I and EM II are approximations of mantle end-members taken from Hart et al. (1992). crustal components, up to $90 \%$ according to those authors. Thus, following Castorina et al. (1996, 1997), the Sr-Nd systematics for Paraguayan rocks seems to be related to an isotopically enriched source, where chemical heterogeneities reflect a depleted mantle metasomatized by small-volume melts and fluids rich in incompatible elements.

The ${ }^{87} \mathrm{Sr} /{ }^{86} \mathrm{Sr}$ vs. ${ }^{143} \mathrm{Nd} /{ }^{144} \mathrm{Nd}$ diagram in Figure 5 shows that the carbonatites extend across the field of Lower Cretaceous Hi-Ti tholeiites of northern Paraná and are intermediate between the two groups of kimberlites (Type I, Gibeon, Namibia, cf. Davies et al. 2001; type II, cf. Smith 1983 and Clark et al. 1991). In the ESr vs. $\varepsilon \mathrm{Nd}$ inset of the figure, isotopic data ranges widely in the enriched quadrant, with the kamafugite field overlapping all lithological types. In the other inset, model ages $\mathrm{T}^{\mathrm{DM}}$ for the overall Alto Paranaíba population fit to $0.99 \pm 0.10 \mathrm{Ga}$. The constant $\mathrm{Sm} / \mathrm{Nd}$ ratio in these rocks allows considering $\mathrm{Nd}$ ages as indicative of the main metasomatic event that affected the lithosphere beneath the Alto Paranaíba region.

\section{Nd-model ages}

Despite their limited petrological meaning, $\mathrm{Nd}$ ages are useful indicators of metasomatic events that affected tholeiites and alkaline rocks of different regions of Brazil and Paraguay. Data on volcanic rocks of the Paraná Basin indicates $\mathrm{T}^{\mathrm{DM}}(\mathrm{Nd})$ ages that range mainly from 0.5 to 2.1 $\mathrm{Ga}$ for Hi-Ti flood tholeiites and dikes, with a mean peak at $1.1 \pm 0.1 \mathrm{Ga}$. Values for L-Ti tholeiites span between 0.7 and $2.4 \mathrm{Ga}$ for L-Ti tholeiites, with a mean peak at $1.6 \pm$ $0.3 \mathrm{Ga}$ (Comin-Chiaramonti et al. 2014). Regarding specifically the tholeiitic rocks of Paraguay, $\mathrm{T}^{\mathrm{DM}}(\mathrm{Nd})$ ages vary from 0.9 to $1.4 \mathrm{Ga}$ for $\mathrm{Hi}-\mathrm{Ti}$ and from 0.7 to 2.8 for $\mathrm{L}-\mathrm{Ti}$, respectively. Apparently, an age increase is observed from North to South and West to East (Comin-Chiaramonti et al. 2007a). T ${ }^{\mathrm{DM}}(\mathrm{Nd})$ ages for the whole Paraná-AngolaNamibia (Etendeka) system reported by these authors vary from 0.8 to $2.4 \mathrm{Ga}$ for $\mathrm{Hi}$-Ti and from 0.8 to $2.7 \mathrm{Ga}$ for $\mathrm{L}-\mathrm{Ti}$, respectively.

Age histograms for Brazilian and Paraguayan tholeiites, alkaline rocks and carbonatites are grouped together in studies by Castorina et al. (1997) and Comin-Chiaramonti et al. (1997). Nd model age values listed more recently (e.g., Gomes \& Comin-Chiaramonti 2005, Bizzi \& Araújo 2005, Ruberti et al. 2005, Scheibe et al. 2005, Comin-Chiaramonti et al. 2007a, 2014, Carlson et al. 2007, Gomes et al. 2011b) allow distinguishing among chronological events in the alkaline magmatism. Thus, the Lower Cretaceous alkaline potassic magmatism includes pre- and post-tholeiite rock types, the first group being only recognized in northern Paraguay. $\mathrm{Nd}$ model ages 
for the pre-tholeiite rocks display two peaks, one at 1.1 $\mathrm{Ga}$ (Valle-mí region) and the other at $1.4 \mathrm{Ga}$ (Amambay region), respectively. The Lower Cretaceous syn- and posttholeiitic magmatism $\mathrm{Nd}$ model ages vary from 0.6 to 0.9 Ga. The Upper Cretaceous alkaline rocks and carbonatites, represented mainly by the Alto Paranaíba complexes in Brazi, as well as the late Lower Cretaceous Misiones and Paleocene Asunción volcanics in Paraguay, yield Nd model ages within the $0.6-1.0 \mathrm{Ga}$ interval. The youngest $\mathrm{T}^{\mathrm{DM}}$ ages are related to the Asunción Tertiary sodic alkaline rocks.

The large variation in model ages seems related to different metasomatic events that took place from Paleoproterozoic to Neoproterozoic. The resulting isotopically distinct alkaline and tholeiitic magmas follow two main subcontinental lithospheric mantle enrichment episodes, at 2.0-1.4 and 1.0-0.5 Ga (Castorina et al. 1997, Comin-Chiaramonti et al. 1997). These metasomatic events, characterized by strong chemical differences in Ti, LILE and HFSF concentrations, may have been precursors to the genesis of tholeiitic and alkaline magmatism in the Paraná Basin.

\section{$\mathrm{Pb}$ isotopes}

Only a few studies present initial $\mathrm{Pb}$ isotopic compositions for ${ }^{206} \mathrm{~Pb} /{ }^{204} \mathrm{~Pb},{ }^{207} \mathrm{~Pb} /{ }^{204} \mathrm{~Pb}$ and ${ }^{208} \mathrm{~Pb} /{ }^{204} \mathrm{~Pb}$ ratios in alkaline-carbonatite complexes of the southeastern Brazilian Platform (e.g., Antonini et al. 2005, Comin-Chiaramonti et al. 2005c, 2007a, Bizzi \& Araújo 2005, Beccaluva et al. 2017, Gomes \& Comin-Chiaramonti et al. 2017). Values are reported for Lower Cretaceous occurrences of Brazil and Paraguay and for some Brazilian Upper Cretaceous complexes in the Alto Paranaíba province (Figs. 6A and 6B). In general, isotopic values vary significantly with the different ages. Brazilian and Paraguayan Lower Cretaceous rocks values range in 17.033-19.968, 15.380-15.641 and 37.373-39.011

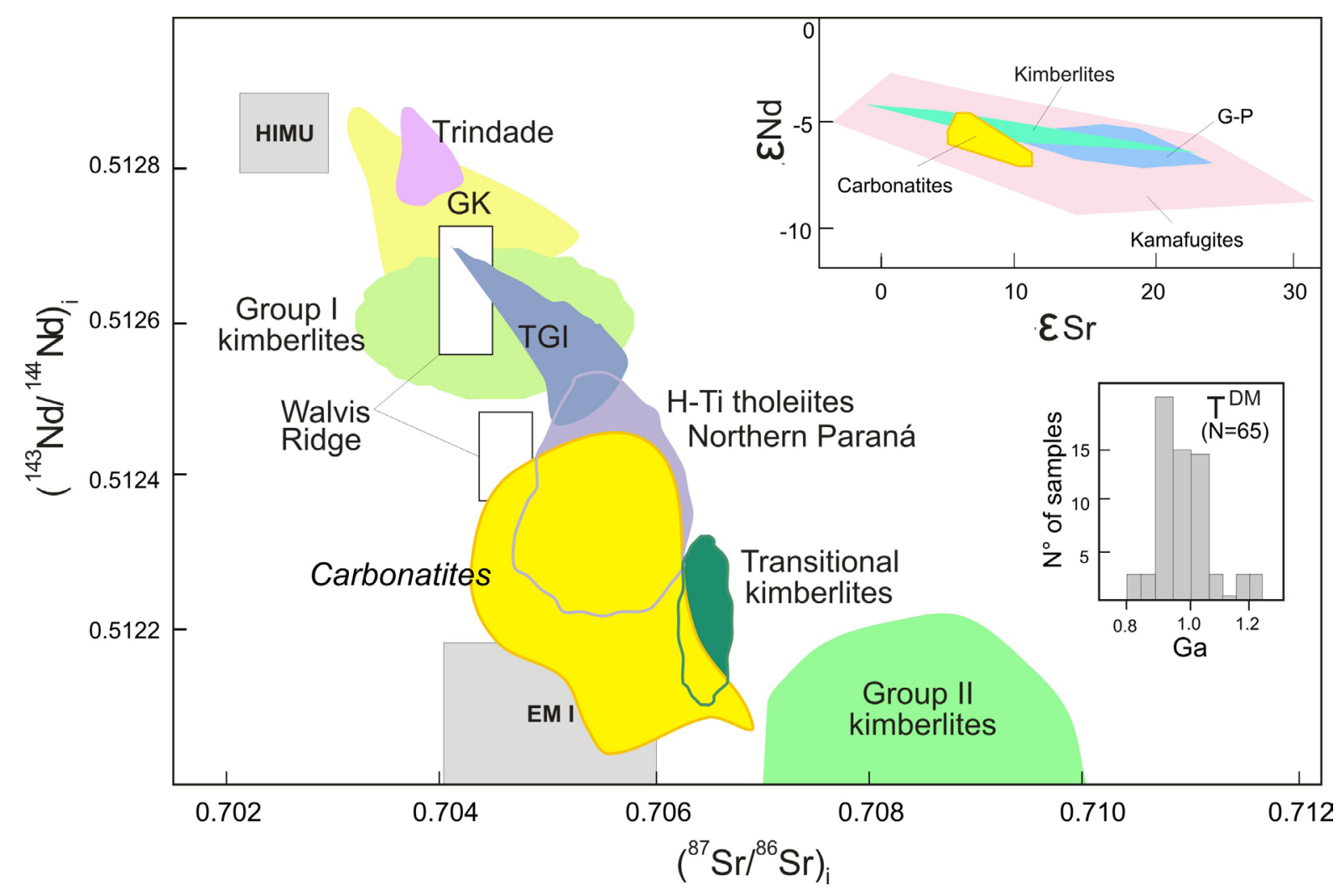

Figure 5. Correlation diagrams for ${ }^{87} \mathrm{Sr} /{ }^{86} \mathrm{Sr}(\mathrm{Sr})_{\mathrm{i}}$ vs. ${ }^{143} \mathrm{Nd} /{ }^{144} \mathrm{Nd}(\mathrm{Nd})_{\mathrm{i}}$ initial ratios of rock types from the Alto Paranaíba province after Bizzi and Araújo (2005; modified by Comin-Chiaramonti et al. 2005c). Data sources: GK, Gibeon kimberlites (Davies et al. 2001); TGI, Tristan da Cunha, Gough and Inaccessible islands (Le Roex 1985; Le Roex et al. 1990); Walvis Ridge (Richardson et al. 1984); Group I, Group II and transitional kimberlites (Smith 1983, Clark et al. 1991), Trindade (Siebel et al. 2000, Marques et al. 2000). Paraná uncontaminated high-Ti tholeiites (Comin-Chiaramonti et al. 1997). HIMU and EM I (Zindler \& Hart 1986, Hart \& Zindler 1989). Insets: Nd model ages $\left(\mathrm{T}^{\mathrm{DM}}\right)$ histograms for Alto Paranaíba rock associations (Gomes \& Comin-Chiaramonti 2005) and fields for different alkaline petrographic types (kamafugites, kimberlites, carbonatites and G-P: glimmerites and mica peridotites) in the time integrated $\varepsilon S r$ vs. $\varepsilon N d$ diagram (Bizzi \& Araújo 2005, modified). T ${ }^{\mathrm{DM}}$ values calculated relative to a depleted mantle: ${ }^{143} \mathrm{Nd} /{ }^{144} \mathrm{Nd}=0.513114$ and ${ }^{147} \mathrm{Sm} /{ }^{144} \mathrm{Nd}=0.222$, cf. Faure (1986). 
intervals for ${ }^{206} \mathrm{~Pb} /{ }^{204} \mathrm{~Pb},{ }^{207} \mathrm{~Pb} /{ }^{204} \mathrm{~Pb}$ and ${ }^{208} \mathrm{~Pb} /{ }^{204}$ ratios, respectively. Higher values for ${ }^{206} \mathrm{~Pb} /{ }^{204} \mathrm{~Pb},{ }^{207} \mathrm{~Pb} /{ }^{204} \mathrm{~Pb}$ and ${ }^{208} \mathrm{~Pb} /{ }^{204} \mathrm{~Pb}$ ratios are typical of a basanite dike that crops out in the Rio Apa region (Valle-mí) in northern Paraguay (K-I, Figs. 6A and 6B). Brazilian Upper Cretaceous occurrences, in turn, show ${ }^{206} \mathrm{~Pb} /{ }^{204} \mathrm{~Pb},{ }^{207} \mathrm{~Pb} /{ }^{204} \mathrm{~Pb}$ and ${ }^{208} \mathrm{~Pb} / 204$ ratios that vary within narrow intervals: $17.51-18.52,15.44$ 15.55 and 38.20-38.76, respectively. These variations are well-evidenced in correlation diagrams involving ${ }^{207} \mathrm{~Pb} /{ }^{204} \mathrm{~Pb}$ and ${ }^{208} \mathrm{~Pb} /{ }^{204} \mathrm{~Pb} v{ }^{206} \mathrm{~Pb} /{ }^{204} \mathrm{~Pb}$, and $\mathrm{Sr}_{\mathrm{i}}$ and $\mathrm{Nd}_{\mathrm{i}}$ vs ${ }^{206} \mathrm{~Pb} /{ }^{204} \mathrm{~Pb}$ initial ratios, respectively, especially for the Brazilian rocks. In the diagrams, Lower Cretaceous carbonatites superpose tholeiites of the Paraná Basin, suggesting a common geodynamic evolution for both alkaline and tholeiitic magmatisms, yet emphasizing the more Sr-enriched composition of coeval Paraguayan rocks and the scatter caused mainly by the values for samples from Valle-mí (K-I). Investigating $\mathrm{Sr}-\mathrm{Nd}$-Pb-isotopes of some selected Paraguayan Cretaceous to Tertiary alkaline-carbonatites, Antonini et al. (2005) postulated that two main mantle components were involved in the genesis of these rocks: an extreme and heterogeneous EM I, which was prevalent in the Lower Cretaceous potassic alkaline magmatism (K-I and K-II), and a HIMU component, which become more important in the late Lower Cretaceous and Paleocene sodic magmatism (LEC-P).

More recently, Beccaluva et al. (2017) provided isotopic data for some intrusions of the Jacupiranga complex. The northwestern body includes alkali gabbros, syenodiorites and syenites around dunites, while the southeastern body consists of clinopyroxenites and rocks of the melteigite-ijolite-urtite series and associated carbonatites. ${ }^{206} \mathrm{~Pb} /{ }^{204} \mathrm{~Pb}$, ${ }^{207} \mathrm{~Pb} /{ }^{204} \mathrm{~Pb}$ and ${ }^{208} \mathrm{~Pb} /{ }^{204}$ ratios for the former petrographic association range from 17.34 to 17.94 , from 15.49 to 15.59 and from 37.94 to 38.93 , respectively. For the latter association, values vary from 17.70 to 17.87 , from 15.47 to 15.50 and from 38.03 to 38.41 , respectively. The carbonatite intrusion shows ${ }^{206} \mathrm{~Pb} /{ }^{204} \mathrm{~Pb},{ }^{207} \mathrm{~Pb} /{ }^{204} \mathrm{~Pb}$ and ${ }^{208} \mathrm{~Pb} /{ }^{204}$ ratios of $17.21,15.42$ and 37.87 , respectively. According to these authors, the silicate and carbonatite intrusions have markedly different $\mathrm{Sr}-\mathrm{Nd}-\mathrm{Pb}$ isotopic compositions, which support derivation of the relative parental magmas from independent mantle sources.

Diagrams for $\mathrm{Pb}$ isotopes (Fig. 7A) define linear arrays that are subparallel to both Lower Cretaceous Paraná tholeiites (Marques et al. 1999a) and the Northern Hemisphere Reference Line (NHRL, cf. Hart 1984). Notably, some kimberlites appear to approach the HIMU mantle component. The Alto Paranaíba rocks fall within the Brazilian Upper Cretaceous alkaline-carbonatite complexes (Fig. 4A), which contain all the magmatic petrographic types of the Paraná Basin. Considering the ${ }^{206} \mathrm{~Pb} /{ }^{207} \mathrm{~Pb}$ vs. ${ }^{87} \mathrm{Sr} /{ }^{86} \mathrm{Sr}$ and
${ }^{143} \mathrm{Nd} /{ }^{144} \mathrm{Nd}$ initial ratio diagrams (Fig. 7B), it should be noticed that the majority of the Alto Paranaíba rocks correspond to peridotite xenoliths, some kimberlites excluded. These latter lithologies show less radiogenic $\mathrm{Nd}$ in comparison to other Upper Cretaceous kimberlites (e.g., Gibeon, cf. Davies et al. 2001).

\section{Re-Os isotopes}

Carbonatite complexes strictly associated with highly potassic mafic-ultramafic rocks of kamafugitic-kimberlitic affinity may represent useful sources of information on the behavior of platinum group elements. Analytical isotopic data on Re, Os and platinoids for rocks from the Alto Paranaíba province are discussed by Bizzi et al. (1994, 1995), Carlson et al. (1996), Araújo et al. (2001), Bizzi and Araújo (2005) and Comin-Chiaramonti et al. (2007a).

The Re-Os isotope systematics (Gomes and CominChiaramonti et al. 2017) does not seem to allow for a clear distinction among rock types in the Alto Paranaíba province, although data provided by Comin-Chiaramonti et al. (2007a) indicates that glimmerites have the highest ${ }^{187} \mathrm{Os} /{ }^{188} \mathrm{Os}$ and ${ }^{187} \mathrm{Re} /{ }^{188} \mathrm{Os}$ ratios (Fig. 7C). Radiogenic ${ }^{187} \mathrm{Os} /{ }^{188} \mathrm{Os}$ ratios for kimberlites and kamafugites range from 0.11 to 0.13 (av. $0.122 \pm 0.005$ ) and from 0.11 to 0.15 (av. $0.134 \pm 0.013$ ), respectively. $\mathrm{T}^{\mathrm{RD}}(\mathrm{Os})$ model ages reported by Bizzi and Araújo (2005) for the Alto Paranaíba petrographic association vary between 1.39 and $1.64 \mathrm{Ga}$, correlating these lithologies to an older event with respect to the $\mathrm{Nd}$ model ages $(0.99 \pm 0.10)$.

\section{Hf isotopes}

Hafnium isotopic composition is only available for baddeleyite separates from cumulatic rocks (magnetitites and apatitites) of Catalão I. Data reported by Guarino et al. (2017) depict a narrow range of initial ${ }^{176} \mathrm{Hf} /{ }^{177} \mathrm{Hf}$ of 0.28248 to 0.28249 and $\varepsilon \mathrm{Hf}_{\mathrm{i}}$ of -10.3 to -10.9 . $\varepsilon \mathrm{Hf}_{\mathrm{i}}$ values are distinct with respect to those of peridotite xenoliths hosted by kamafugites of the Goiás province (Carlson et al. 2007), confirming mantle heterogeneities in the Alto Paranaíba province. Calculated hafnium model ages $\left(\mathrm{T}^{\mathrm{DM}} \mathrm{Hf}=1.0-1.1 \mathrm{Ga}\right.$ ) are coherent to regional tectonomagmagmatic events that affected the central-southern Brazil.

\section{Noble gases}

Only a few carbonatites in the world have been analyzed for noble gases. In Brazil, only two occurrences have so far been investigated: Lower Cretaceous Jacupiranga calciocarbonatites for forsterite and apatite, and Upper Cretaceous Tapira calciocarbonatites for apatite. Analytical data for $\mathrm{Ar}, \mathrm{Xe}, \mathrm{Kr}, \mathrm{Ne}$, and He is presented in Sasada et al. (1997) and discussed in a review paper by Comin-Chiaramonti et al. (2007a). A summary provided by the latter authors suggests that: 

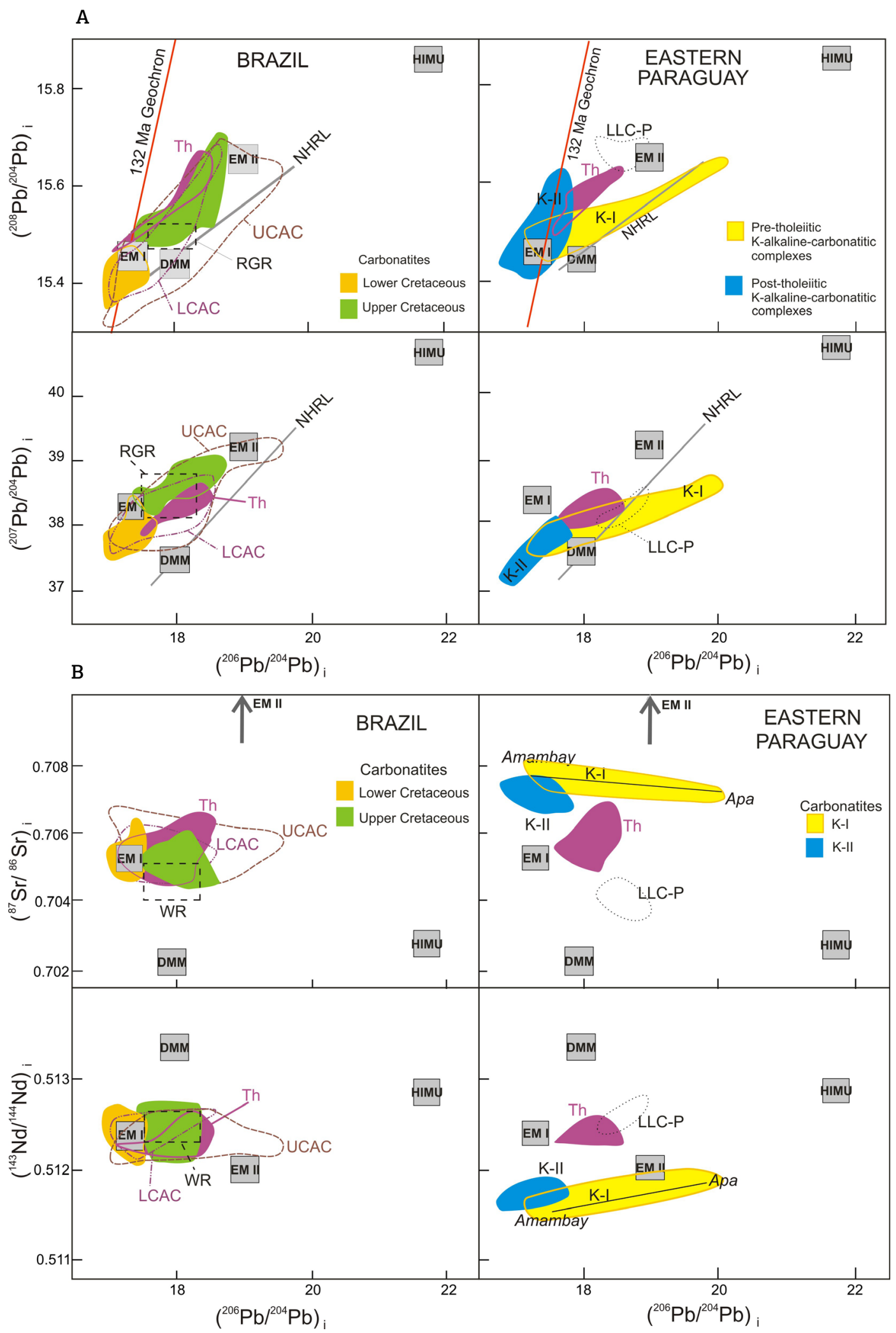

Figure 6. Correlation diagrams for $(\mathrm{A}){ }^{207} \mathrm{~Pb} /{ }^{204} \mathrm{~Pb}$ and ${ }^{208} \mathrm{~Pb} / 204 \mathrm{~Pb}$ vs. ${ }^{206} \mathrm{~Pb} /{ }^{204} \mathrm{~Pb}$ initial ratios and for $(\mathrm{B}){ }^{206} \mathrm{~Pb} /{ }^{204} \mathrm{~Pb}$ initial ratios vs. $\mathrm{Sr}_{\mathrm{i}}$ and $\mathrm{Nd}_{\mathrm{i}}$ of rock types of southern Brazil and eastern Paraguay (after Comin-Chiaramonti et al. 2005c, modified). Brazil: LCAC and UCAC, Lower Cretaceous and Upper Cretaceous alkaline-carbonatite magmatism, respectively. Eastern Paraguay: LLC-P, late Lower Cretaceous-Paleocene sodic alkaline magmatism. NHRL, North Hemisphere Reference Line (Hart 1984); Th, Paraná tholeiites; WR, Walvis Ridge; 132 Ma geochron according to Ewart et al. (2004). Data sources are given in Comin-Chiaramonti et al. (2005c). Further information as in Figure 4. 
apatites from both carbonatite complexes are in the same range of possible derived sources (e.g., HIMU and MORB);

sources are enriched in F;

carbonatites are unlikely to derive from subduction-related carbon, whereas they support a C-O fractionation model of mantle-derived sources.

A
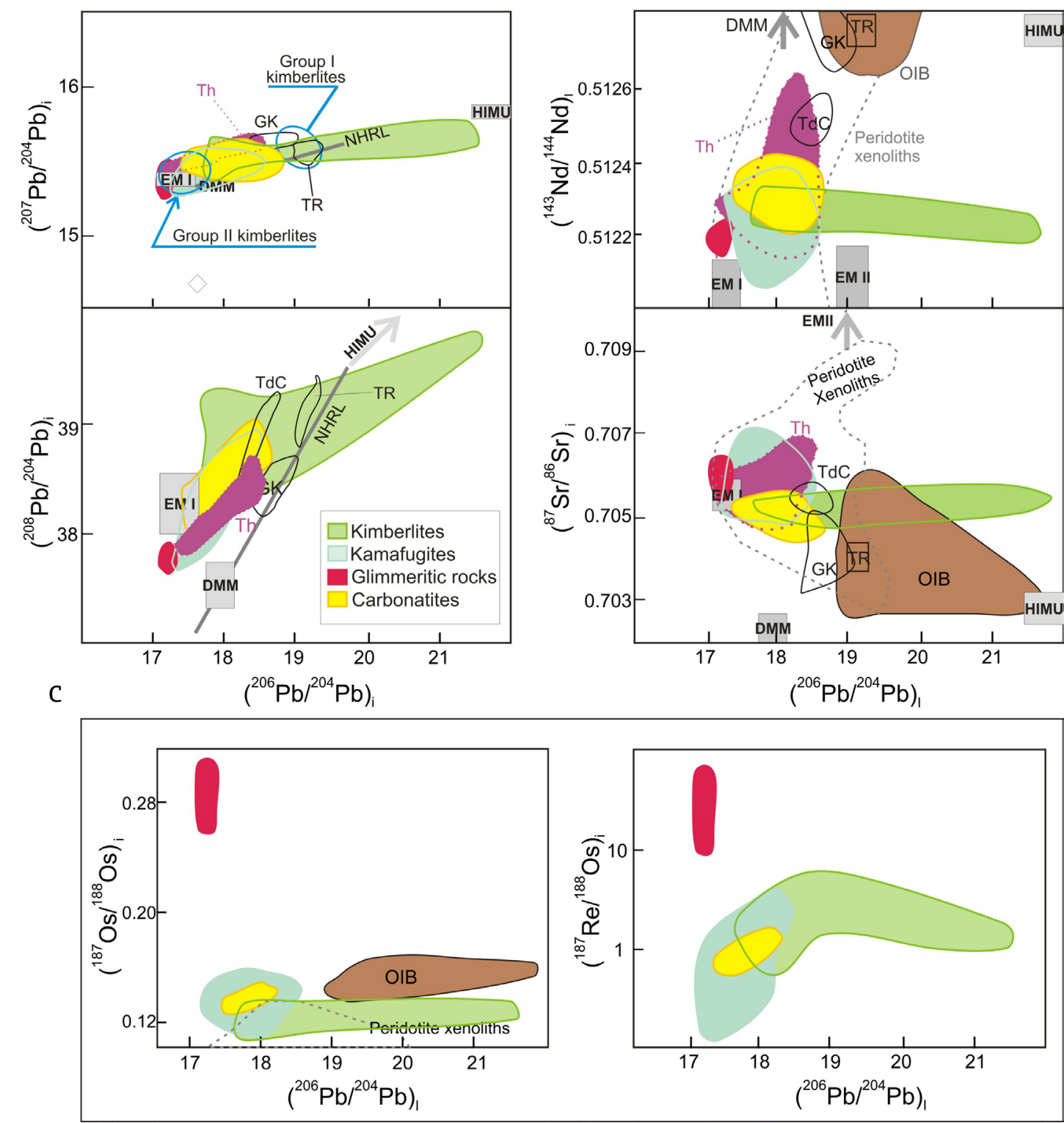

\section{PETROLOGICAL CONSIDERATIONS}

Carbonatite melts from all over the world are currently assigned to some main processes:

- immiscibility of silicate and carbonatite liquids (e.g., Baker \& Wyllie 1990, Kjarsgaard \& Hamilton 1988, 1989, Lee \& Wyllie 1996, 1997, 1998b);

B

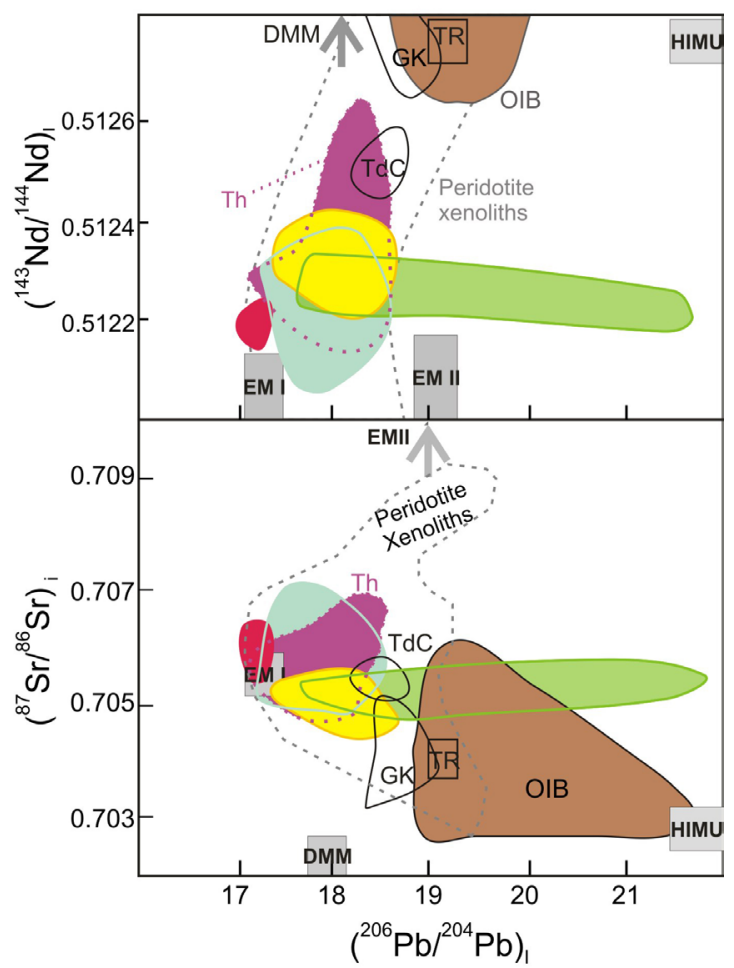

Figure 7. Graphical representation of rock samples from the Alto Paranaíba province in correlation diagrams involving isotopic ratios: $(\mathrm{A})\left({ }^{206} \mathrm{~Pb} /{ }^{204} \mathrm{~Pb}\right)_{\mathrm{i}}$ vs. $\left({ }^{207} \mathrm{~Pb} /{ }^{204} \mathrm{~Pb}\right)_{\mathrm{i}}$ and $\left({ }^{208} \mathrm{~Pb} /{ }^{204} \mathrm{~Pb}\right)_{\mathrm{i}}$; $(\mathrm{B})\left({ }^{206} \mathrm{~Pb} /{ }^{204} \mathrm{~Pb}\right)_{\mathrm{i}}$ vs. $\left({ }^{143} \mathrm{Nd} /{ }^{144} \mathrm{Nd}\right)_{\mathrm{i}}$ and $\left({ }^{87} \mathrm{Sr} /{ }^{86} \mathrm{Sr}\right)_{\mathrm{i}} ;(\mathrm{C})\left({ }^{206} \mathrm{~Pb} /{ }^{204} \mathrm{~Pb}\right)_{\mathrm{i}}$ vs. $\left({ }^{187} \mathrm{Os} /{ }^{188} \mathrm{Os}\right)_{\mathrm{i}}$ and $\left({ }^{187} \mathrm{Re} /{ }^{188} \mathrm{Os}\right)_{\mathrm{i}}$ (after Bizzi \& Araújo 2005, modified; cf. also Gomes \& Comin-Chiaramonti 2017). OIB, Ocean islands basalts and peridotite xenoliths (Smith 1983; Smith et al. 1985; Clark et al. 1991); TdC, Tristan da Cunha-Gough-Inaccessible islands (Le Roex et al. 1990); TR, Trindade island (Marques et al. 2000). Further information as in Figures 4, 5 and 6. 
- extreme fractionation from carbonate-rich silicatic magma (e.g., Otto \& Wyllie 1993, Lee \& Wyllie 1994, Church $\&$ Jones 1995);

a primary mantellic origin such as melting of metasomatized source (Chakhmouradian 2006) or melting of recycled oceanic crust components under mantle conditions (Hoernle et al. 2002, Song et al. 2017).

Petrogenetic studies performed on a selected number of prominent Cretaceous complexes, as exemplified by Barra do Itapirapuã (Ruberti et al. 2002), Ipanema (Guarino et al. 2011), Juquiá (Beccaluva et al. 1992, Azzone et al. 2013) and Lages (Traversa et al. 1996) in Brazil and by Cerro Chiriguelo (Castorina et al. 1996, 1997) and Cerro Sarambí (Gomes et al. 2011b) in Paraguay indicate that processes of fractional crystallization and liquid immiscibility from parental alkaline mafic magmas are the main responsible for the generation of carbonatitic liquids, as suggested by field relationships and geochemical characteristics (cf. also Comin-Chiaramonti et al. 2014).

A very consistent hypothetical model for the origin of the Juquiá carbonatites was discussed by Beccaluva et al. (1992) that considers multistage evolution under nearly closed system conditions involving:

assemblage fractionation closely comparable to olivine clinopyroxenite and subordinate olivine alkali gabbro cumulates from parental basanitic melt leading to the formation of essexitic magma;

derivation of least differentiated mafic nepheline syenite from essexitic magma by withdrawal of cumulitic syenodiorites;

- exsolution of carbonate fluid from a $\mathrm{CO}_{2}$-enriched mafic nepheline syenite magma, the magma itself being also submitted to continued fractionation to form melteigite-ijolite-urtite cumulates;

- formation of residual nepheline syenitic rocks (and phonolitic dikes) leaving out orthocumulates of nepheline syenites.

Based on field, petrographic, mineralogical, chemical and isotopic evidence, Brod et al. (2013) consider the Tapira occurrence as resulting from the complex interplay of several petrogenetic processes: liquid immiscibility, crystal fractionation, and degassing/metasomatism. Their study strongly supports silicate-carbonate liquid immiscibility from decoupling of geochemical pairs such as $\mathrm{Nb} / \mathrm{Ta}$ and $\mathrm{Zr} / \mathrm{Hf}$, rotation of REE patterns, which cross over the patterns of the primitive liquids, and matching and opposite enrichment-depletion trace elements relationships in spider diagrams of conjugate immiscible liquids.

In spite of the isotopic data support to the interpretation that the Cretaceous alkaline-carbonatites are mostly formed by processes related to immiscibilty and fractional crystallization from a common parental magma, higher ${ }^{87} \mathrm{Sr} /{ }^{86} \mathrm{Sr}$ initial ratios found in samples from a few occurrences (e.g., Barra do Itapirapuã, Ipanema, Jacupiranga, Juquiá, etc.) seem to indicate that contamination processes should not be discarded, particularly in some complexes where border facies are in contact with granitic country rocks in the latest stage of carbonatite intrusion. In the past, Roden et al. (1985) and Gaspar (1989), investigating the Jacupiranga complex, also interpreted isotopic heterogeneities of some rocks as due to crustal contamination. In contrast, based on isotopic data, Huang et al. (1995) refuted any significant contribution of contamination processes affecting the evolution of the carbonatites and clinopyroxenites. In a recent study, Chmyz et al. (2017) provided mineralogical, textural and geochemical evidence of crustal contamination in the formation of the weakly silica-undersaturated rocks of Jacupiranga.

A complex model combining crustal assimilation, fractional crystallization and fluid immiscibility processes was proposed for the carbonatites of Cataláo I by Cordeiro et al. (2011). A compositional trend is assigned to multiple batches of immiscible and/or residual melts derived from fractional crystallization of a carbonated-silicate parental magma (phlogopite picrite) contaminated to a variable amount with continental crust material. A second trend involved interaction of previously-formed magmatic carbonatites with late-stage or post-magmatic carbohydrothermal fluids.

Conversely, Beccaluva et al. (2017) suggested that in the Jacupiranga complex carbonatitic and silicatic rocks originated from independent rather than common mantle sources. Different isotopic data trends indicate that these petrographic types do not exhibit any evidence of being genetically related among themselves. The authors mention the absence of carbonatite ocelli in the associated silicate rocks and the presence of fluid and melt inclusions in apatites from carbonatites (suggestive of high depth trapping) as features indicative of origin at mantle depths. Based on geochemical evidence (patterns for REE and isotopic data for sulphur and iron indicating a primitive nature), Beccaluva et al. (2017) also advocated that the hypothesis of carbonatites being associated with shallow level immiscibility is less plausible.

A phlogopite-bearing carbonate-metasomatized heterogeneous peridotite source is assigned to different domains of the Brazilian Platform (e.g., Gibson et al. 1995b, 1999, 2006, Comin-Chiaramonti et al. 1997, 2014, Thompson et al. 1998, Brotzu et al. 2005, Guarino et al. 2017). Such mantle source heterogeneities were recognized at regional scale, the isotopic signatures of the Alto Paranaíba rocks being distinct 
from those of the Goiás province and the Ponta Grossa Arch, as demonstrated by Guarino et al. (2017).

The geodynamic models regarding the Cretaceous carbonatitic and alkaline magmatism of the Brazilian Platform are related:

to mantle plume and subcontinental lithospheric mantle (SCLM) interactions;

to low-degree partial melts of metasomatized SCLM due to the reactivation of ancient fault zones (cf. Gomes \& Comin-Chiaramonti, 2017).

Gibson et al. (1995a, 1995b, 1999), Thompson et al. (1998) and Natali et al. (2018) suggested for the alkaline and tholeiitic magmatism an origin associated with the interaction of melts from asthenospheric sources attributed to different mantle plumes (i.e. Tristan da Cunha and Trindade mantle plumes) with melts derived of a previously metasomatized lithosperic mantle source. On the other hand, Comin-Chiaramonti et al. (1997, 1999, 2002, 2005c, 2007a), Castorina et al. (1997), Alberti et al. (1999), Ernesto et al. (2002) and Riccomini et al. (2005) proposed for the alkaline-carbonatite events in the Paraná-Angola-Namíbia system an origin from metasomatized lithospheric mantle sources without the contribution of plume-derived components.

\section{ECONOMIC ASPECTS}

The economic importance of carbonatites in Brazil results from the intense weathering of alkaline rocks, mainly of ultrabasic and carbonatic composition. Lateritic soils thus formed can reach more than 200 m thick, especially in complexes of the Ribeira Valley and Alto Paranaíba regions. Mineral deposits formed by either supergene alteration or residual concentration of primary minerals during long periods (Gomes et al. 1990). A few sources of mineralization in contact with eluvial material and, more scarcely, fresh rocks are described. Mineral deposits of major importance include phosphate, niobium and vermiculite, whereas subordinate mineralizations are represented by titanium, rare earths, barite, bauxite, fluorspar, etc. Economic aspects of carbonatites are presented by Berbert (1984), Rodrigues and Lima (1984) and Gomes et al. (1990). However, such aspects are discussed in more detail in a compilation work by Biondi (2005), one of the most valuable and comprehensive sources of economic data on carbonatites. The author distinguishes among various types of alkaline rock associations containing economic or potentially economic mineral deposits. The most important mineral ores are represented by miaskitic alkaline complexes with syenites + pyroxenites + ijolites + carbonatites, and/or their effusive equivalents as main petrographic types. Recently, Oliveira et al. (2017) observed that the distinct evolution trends reaching late-stage rocks from Catalão I coincide with a shift from a Nb-rich to a REE- and Ba-rich mineralization environment.

Finally, in Cerro Manomó, Bolivia, extensive and important enrichments in $\mathrm{U}$ and $\mathrm{Th}$ are associated with carbonatite blocks (Fletcher et al. 1981, CominChiaramonti et al. 2011).

\section{CONCLUDING REMARKS}

In the southeastern Brazilian Platform, Lower Cretaceous and Upper Cretaceous episodes of alkaline-carbonatite magmatism took place along tectonic lineaments genetically related to regional structural features like the Ponta Grossa Arch and the Alto Paranaíba Uplift in Brazil and the Ponta Pora Arch in Paraguay. The carbonatites occupy inner parts of circular/oval- shaped complexes or appear as dikes and veins that cut across associated alkaline and regional rocks. In some complexes, they result from multistage intrusions of varied composition. Carbonatites are usually found in contact with cumulates of large compositional variation such as ultrabasic (dunites, peridotites, pyroxenites) lithologies, members of the melteigite-ijolite-urtite series, nepheline syenites and syenites, glimmerites, kamafugites, kimberlites, phoscorites, and unimineralic rock types such as apatitite, magnetitite and flogopitite in a few complexes. The country rocks were in most cases deeply affected by fenitization, giving origin mainly to syenitic types. Such processes promoted flogopitization, amphibolitization and aegirinization of pyroxenitic rocks due to the action of highly concentrated alkalis, together with $\mathrm{CO}_{2}$ and $\mathrm{H}_{2} \mathrm{O}$ enriched fluids derived from carbonatitic and syenitic magmas, as well evidenced in Ribeira Valley and Alto Paranaíba complexes.

In an overall classification, Cretaceous carbonatites can be placed into two major groups: primary or magmatic, and hydrothermal. The major Brazilian complexes of the Ribeira Valley and Alto Paranaíba correspond to the first group, whereas Barra do Itapirapuã in Brazil, Cerro Chiriguelo in Paraguay, and Cerro Manomó in Bolivia, are included in the second group. Additional occurrences are represented by small dikes and aggregates of carbonate material (ocelli) present in the interior of fine- and coarse-grained alkaline silicate rocks, namely basanite and ijolite. However, it must be stressed that, in 
some magmatic occurrences, carbohydrothermal events were also registered.

Carbonatites vary considerably in major oxide concentrations, from calciocarbonatites to magnesiocarbonatites to ferrocarbonatites, but the three rock types are rarely associated in the same complex. Besides their richness in elements such as $\mathrm{K}, \mathrm{Ba}, \mathrm{Th}, \mathrm{U}, \mathrm{Sr}, \mathrm{P}$ and REE, and $\mathrm{F}$ and $\mathrm{Cl}$ as well, and their high LREE content and $\mathrm{La} / \mathrm{Lu}$ ratio, carbonatites exhibit, in general, a strongly fractionated pattern for REE, mostly controlled by the presence, concentration and variable distribution of accessory phases represented by phosphates, oxides, REEcarbonates and fluorocarbonates minerals (e.g., apatite, monazite, pyrochlore, ancylite, bastnäesite, synchysite, etc.). In spite of some scatter observed, the behavior of incompatible elements points to negative $\mathrm{Rb}, \mathrm{K}, \mathrm{P}, \mathrm{Hf}-\mathrm{Zr}$ and Ti anomalies, contrasting with positive $\mathrm{Ba}$, Th- $\mathrm{U}$ and La-Ce peaks. A remarkable scattering also characterizes the REE distribution, REE-fluorocarbonates being relatively abundant in late ferrocarbonatites. Different behaviors can be distinguished: a strong increase from $\mathrm{Lu}$ to $\mathrm{La}$, flat REE with a relative weakly decrease from $\mathrm{La}$ to $\mathrm{Lu}$, and concave patterns with a HREE plateau followed by a steady increase from Dy to LREE.

Notably, significant differences in C-O isotope compositions are observed in primary carbonates of alkaline rocks and associated carbonatites. The variations are interpreted as due mainly to isotope exchange between carbonates and $\mathrm{H}_{2} \mathrm{O}-\mathrm{CO}_{2}$ rich fluids, with the isotopic modifications occurring at low temperatures $\left(400-80^{\circ} \mathrm{C}\right)$ in a hydrothermal environment with $\mathrm{CO}_{2} / \mathrm{H}_{2} \mathrm{O}$ fluids ranging from 0.8 to 1 . Two main paths of $\delta^{18} \mathrm{O}$ and $\delta^{13} \mathrm{C}$ fractionation associated with different emplacement levels (i.e., deep-seated up to near surface, or near-surface environments) are distinguished. Agents such as weathering and groundwater fluids, that seem to have also influenced post-magmatic changes, could explain the secondary isotopic variations, as indicated by the largest enrichment in heavy oxygen.

In general, $\mathrm{Sr}-\mathrm{Nd}$ isotopes and trace-element data for the alkaline rocks shows that coeval carbonatites and primary carbonates reflect the composition of the mantle source. In particular, $\mathrm{Sr}$ and $\mathrm{Nd}$ isotopic data indicate that the carbonatite system was dominated by mantle component(s) without appreciable crustal contamination. Model ages also evidence that the alkaline rocks and associated carbonatites experienced two chemically different episodes of mantle enrichment in Proterozoic times, at $2.0-1.4 \mathrm{Ga}$ and $1.0-0.5 \mathrm{Ga}$, respectively.
Significant $\mathrm{H}_{2} \mathrm{O}, \mathrm{CO}_{2}$ and $\mathrm{F}$ are also expected in the mantle source, as suggested by the occurrence of the carbonatitic rocks.

Combined $\mathrm{Pb}, \mathrm{Sr}$ and $\mathrm{Nd}$ isotopic data reveal the contribution of two mantle components as source:

an extreme and heterogeneous EM I component, which was active in the formation of the Lower Cretaceous alkaline potassic rocks;

- a depleted component, which is believed to have played an important role in the sodic magmatism, spanning in age from Permotriassic to Paleocene.

Mixing processes mainly involving HIMU and EM I end-members, DMM and EM I subordinate, as well as crustal latu sensu components (e.g., EM II) were also proposed. For the overall occurrences of the Paraná-AngolaNamibia system, data emphasizes carbonatite plots that fall close to EM I/DMM-HIMU mixing lines for both $\mathrm{Pb}-\mathrm{Sr}$ and $\mathrm{Pb}-\mathrm{Nd}$.

Os isotopic results for silicate alkaline rocks (kamafugites, kimberlites) associated with carbonatites of the Alto Paranaíba province are indicative of lithospheric mantle sources that experienced LILE enrichment by fluid/melt metasomatism at $-1 \mathrm{Ga}$, probably during the mobile belt formation along the western border of the São Francisco Craton.

Fractional crystallization and liquid immiscibility processes from parental alkaline mafic magmas are thought to be the main responsible for the generation of Cretaceous carbonatite fluids in the Brazilian Platform, crustal contamination being considered to have played a minor role. Degassing, metasomatism and post-magmatic interaction with carbohydrothermal fluids were also recognized in various occurrences. However, some carbonatites do not present a clear genetic association with silicate rocks, which suggests the possibility of a primary mantle origin for the carbonatites. For the generation of alkaline-carbonatite magmatism, a heterogeneous phlogopite-bearing carbonate-metasomatized mantle source is assigned to different domains of the Brazilian Platform.

\section{ACKNOWLEDGMENTS}

The authors thank Fapesp for the financial support to this research (Grants: 2016/23399-4, CBG; 2012/060826, ER; 2017/03768-8, RGA). They also thank for the reviewers L. Beccaluva and E.S.R. Barbosa for the valuable suggestions to improve the manuscript. 


\section{REFERENCES}

Alberti A., Castorina F., Censi P., Comin-Chiaramonti P., Gomes C.B. 1999. Geochemical characteristics of Cretaceous carbonatites from Angola. Journal of African Earth Sciences, 29(4):735-759. https://doi. org/10.1016/S0899-5362(99)00127-X

Algarte J.P. 1972. A influência dos arqueamentos cratônicos no condicionamento das alcalinas dos estados de São Paulo e Paraná. In: Congresso Brasileiro de Geologia, 26., Belém. Anais..., p. 65-69.

Almeida F.F.M. 1971. Condicionamento Tectônico do Magmatismo Alcalino Mesozóico do Sul do Brasil e do Paraguai Oriental. Anais da Academia Brasileira de Ciências, 43:835-836

Almeida F.F.M. 1983. Relações tectônicas das rochas alcalinas mesozoicas da região meridional da Plataforma Sul-Americana. Revista Brasileira de Geociências, 13:139-158.

Alves A.D. 2003. Rochas vulcanoclásticas do complexo alcalino de Poços de Caldas - MG/SP. MS Dissertation, Universidade de São Paulo, São Paulo, 106 p.

Amaral G. 1978. Potassium-argon studies on the Jacupiranga alkaline district, state of São Paulo, Brazil. In: International Symposium on Carbonatites, 1., Poços de Caldas. Proceedings..., p. 297-302.

Amaral G., Bushee J., Cordani U.G., Kawashita K., Reynolds J.H. 1967. Potassium-argon ages of alkaline rocks from Southern Brazil. Geochimica et Cosmochimica Acta, 31:117-142. https://doi. org/10.1016/S0016-7037(67)80041-3

Andrade F.R.D. 1998. Geoquímica do sistema de alteração do carbonatito de Barra do Itapirapuã. $\mathrm{PhD}$ Thesis, Universidade Estadual de São Paulo, Rio Claro, 136 p.

Andrade F.R.D., Möller P., Höndorf A. 1999a. The effect of hydrothermal alteration on the $\mathrm{Sr}$ and $\mathrm{Nd}$ signatures of the Barra do Itapirapuã carbonatite. Journal of Geology, 107:177-191. https:// doi.org/10.1086/314339

Andrade F.R.D., Möller P., Lüders V., Dulski P., Gilg H.A. 1999. Hydrothermal rare earth elements mineralization in the Barra do Itapirapuã carbonatite, southern Brazil: behavior of selected trace elements and stable isotopes (C, O). Chemical Geology, 155:91-113.

Antonini P., Gasparon M., Comin-Chiaramonti P., Gomes C.B. 2005. Post-Palaeozoic magmatism in Eastern Paraguay: $\mathrm{Sr}-\mathrm{Nd}-\mathrm{Pb}$ isotope compositions. In: Comin-Chiaramonti P. \& Gomes C.B. (eds.), Mesozoic to Cenozoic alkaline magmatism in the Brazilian Platform. São Paulo, Edusp/Fapesp, p. 57-70.

Araújo A.L.N., Carlson R.W., Gaspar J.C., Bizzi L.A. 2001. Petrology of kamafugites and kimberlites from the Alto Paranaiba Alkaline Province, Minas Gerais, Brazil. Contributions to Mineralogy and Petrology, 142:163-177. DOI: 10.1007/s004100100280

Azzone R.G., Enrich G.E.R., Gomes C.B., Ruberti E. 2012. An olivine gabbronorite occurrence associated with the Jacupiranga maficultramafic alkaline-carbonatite complex (SE Brazil). In: 34th International Geological Congress, Brisbane. Abstract Book, p. 495.

Azzone R.G., Enrich G.E.R., Gomes C.B., Ruberti E. 2013. Trace element composition of parental magmas from ultramafic cumulates determined by in situ mineral analysis: the Juquiá mafic-ultramafic alkaline-carbonatite massif, SE Brazil. Journal of South American Earth Sciences, 41:5-21. https://doi.org/10.1016/j. jsames.2012.07.005

Baker M.B. \& Wyllie P.J. 1990. Liquid immiscibility in a nephelinitecarbonate system at 25 kbars and implications for carbonatite origin. Nature, 346:168-170. DOI: 10.1038/346168a0

Barabino G., Gomes C.B., Traversa G. 2007. The Lages diatremes: mineral composition and petrological implications. Anais da
Academia Brasileira de Ciências, 79:473-501. http://dx.doi. org/10.1590/S0001-37652007000300010

Barbieri M., Beccaluva L., Brotzu P., Conte A., Garbarino C., Gomes C.B., Loss E., Macciotta G., Morbidelli L., Scheibe L.F., Tamura R.M., Traversa G. 1987. Petrological and geochemical studies of alkaline rocks from continental Brazil. Geochimica Brasiliensis, 1:109-138

Barbosa E.S.R. 2009. Mineralogia e petrologia do complexo carbonatítico-foscorítico de Salitre, MG. PhD Thesis, Universidade de Brasília, Brasília, 257 p.

Barbosa E.S.R., Brod J.A., Cordeiro P.F.O., Junqueira-Brod T.C. 2012a. Variações composicionais de olivinas do complexo alcalino-carbonatítico de Salitre, MG. Revista Brasileira de Geociências, 42:729-743. http://dx.doi.org/10.5327/ Z0375-75362012000400006

Barbosa E.S.R., Brod J.A., Junqueira-Brod T.C., Dantas E.L., Cordeiro P.F.O., Gomide C.S. 2012b. Bebedourite from its type area (Salitre I complex): a key petrogenetic series in the Late Cretaceous Alto Paranaíba kamafugite-carbonatite-phoscorite association, Central Brazil. Lithos, 144-145:56-72. https://doi.org/10.1016/j. lithos.2012.04.013

Beccaluva L., Barbieri M., Born H., Brotzu P., Coltorti M., Conte A., Garbarino C., Gomes C.B., Acciotta M., Morbidelli L., Ruberti E., Siena F., Traversa G. 1992. Fractional crystallization and liquid immiscibility processes in the alkaline-carbonatite complex of Juquiá (São Paulo, Brazil). Journal of Petrology, 33:1371-1404. https://doi.org/10.1093/ petrology/33.6.1371

Beccaluva L., Bianchini G., Natali C., Siena F. 2017. The alkalinecarbonatite of Jacupiranga (Brazil): magma genesis and mode of emplacement. Gondwana Research, 44:157-177. https://doi. org/10.1016/j.gr.2016.11.010

Berbert C.O. 1984. Carbonatites and associated mineral deposits in Brazil. Report of International Research and Development Cooperation - ITIT Projects n. 8316. Research on Mineral Deposits Associated with Carbonatite in Brazil. International Research and Development Cooperation. p. 131-152.

Berrocal J. \& Fernandes C. 1996. Seismicity in Paraguay and neighbouring regions. In: Comin-Chiaramonti P. \& Gomes C.B. (eds.), Alkaline magmatism in central-eastern Paraguay. Relationships with coeval magmatism in Brazil. São Paulo, Edusp/Fapesp, p. 57-66.

Biondi J.C. 2005. Brazilian mineral deposits associated with alkaline and alkaline-carbonatite complexes. In: Comin-Chiaramonti P. \& Gomes C.B. (eds.), Mesozoic to Cenozoic alkaline magmatism in the Brazilian Platform. São Paulo, Edusp/Fapesp, p. 707-750.

Bizzi L.A. \& Araújo A.L.N. 2005. Dynamic of mantle-derived magmatism in the southwestern São Francisco Craton, Brazil. In: Comin-Chiaramonti P. \& Gomes C.B. (eds.), Mesozoic to Cenozoic alkaline magmatism in the Brazilian Platform. São Paulo, Edusp/ Fapesp, p. 341-365.

Bizzi L.A., De Wit M.J., Smith C.B., Mcdonald I., Armstrong R.A. 1995. Heterogeneous enriched mantle materials and Dupal-type magmatism along the southwestern margin of the San Francisco Craton, Brazil. Journal of Geodynamics, 20:469-491.

Bizzi L.A., Smith C.B., De Wit M.J., Mcdonald I., Armstrong R.A. 1994. Isotope characteristics of the lithospheric mantle underlying the SW San Francisco craton margin, Brazil. In: International Symposium on the Physics and Chemistry of the Upper Mantle, São Paulo. Invited Lectures..., p. 227-256. 
Born H. 1971. O complexo alcalino de Juquiá. PhD Thesis, Universidade de São Paulo, São Paulo, 177 p.

Boynton W.V. 1984. Cosmochemistry of the Rare Earth Elements: meteorite studies. In: Henderson P. (ed.), Rare Earth Element geochemistry. Amsterdam, Elsevier, p. 63-114

Brod J.A. 1999. Petrology and geochemistry of the Tapira alkaline complex, Minas Gerais State, Brazil. PhD Thesis, University of Durham, Durham. 486 p.

Brod J.A., Barbosa E.S.R., Junqueira-Brod T.C., Gaspar J.C., Diniz-Pinto H.S., Sgarbi P.B.A., Petrinovic L.A. 2005. The Late-Cretaceous Goiás alkaline province (GAP), Central Brazil. In: Comin-Chiaramonti P. \& Gomes C.B. (eds.), Mesozoic to Cenozoic alkaline magmatism in the Brazilian Platform. São Paulo, Edusp/Fapesp, p. 261-340.

Brod J.A., Gibson S.A., Thompson R.N., Junqueira-Brod T.C., Seer H.J., Moraes L.C., Boaventura G.R. 2000. The kamafugitecarbonatite association in the Alto Paranaíba Igneous Province (APIP), Southeastern Brazil. Revista Brasileira de Geociências, 30:408-412

Brod J.A., Junqueira-Brod T.C., Gaspar J.C., Petrinovic I.A., Valente S.C., Corval A. 2013. Decoupling of paired elements, crossover REE patterns, and mirrored spider diagrams: Fingerprinting liquid immiscibility in the Tapira alkaline-carbonatite complex, SE Brazil. Journal of South American Earth Sciences, 41:41-56. https://doi. org/10.1016/j.jsames.2012.04.013

Brotzu P., Melluso L., D’Amelio F., Lustrino M. 2005. Mafic/ultramafic potassic dykes and felsic intrusions of the Serra do Mar igneous province (SE Brazil): a review. In: Comin-Chiaramonti P. \& Gomes C.B. (eds.), Mesozoic to Cenozoic alkaline magmatism in the Brazilian Platform. São Paulo, Edusp/Fapesp, p. 443-472.

Carlson R.W., Araújo A.L.N., Junqueira-Brod T.C., Gaspar J.C., Brod J.A., Petrinovic I.A., Hollanda M.H.B.M., Pimentel M.M., Sichel S. 2007. Chemical and isotopic relationships between peridotite xenoliths and mafic-ultrapotassic rocks from Southern Brazil. Chemical Geology, 242:415-434. https://doi.org/10.1016/j.chemgeo.2007.04.009

Carlson R.W., Esperança S., Svisero D.P. 1996. Chemical and Os isotopic study of Cretaceous potassic rocks from Southern Brazil. Contributions to Mineralogy and Petrology, 125:393-405.

Carvalho W.J. \& Bressan S.R. 1997. Depósitos de fosfatos, nióbio, titânio, terras raras e vermiculita de Catalão I, Goiás. In: Schobbenhaus C., Queiroz E.T., Coelho C.E.S. (eds.), Principais depósitos minerais brasileiros - Rochas e minerais industriais._Departamento Nacional da Produção Mineral. v. VI, parte C, p. 69-93.

Castorina F., Censi P., Barbieri M., Comin-Chiaramonti P., Cundari A. Gomes C.B., Pardini G. 1996. Carbonatites from Eastern Paraguay: a comparison with coeval carbonatites from Brazil and Angola. In: Comin-Chiaramonti P., Gomes C.B. (eds.), Alkaline magmatism in central-eastern Paraguay. Relationships with coeval magmatism in Brazil. São Paulo, Edusp/Fapesp, p. 231-248.

Castorina F., Censi P., Comin-Chiaramonti P., Piccirillo E.M., Alcover Neto A., Gomes C.B., Almeida T.I.R., Speziale S., Toledo M.C.M. 1997. Carbonatites from Eastern Paraguay and genetic relationships with potassic magmatism: C, O, Sr and $\mathrm{Nd}$ isotopes. Mineralogy and Petrology, 61:237-260

Censi P., Comin-Chiaramonti P., Demarchi G., Longinelli A., Orué D. 1989. Geochemistry and C-O isotopes of the Chiriguelo carbonatite, Northeastern Paraguay. Journal of South American Earth Sciences, 3:295-303. https://doi.org/10.1016/0895-9811(89)90035-7

Cerva-Alves T., Remus M.V.D., Dani N., Basei M.A.S. 2017. Integrated fied, mineralogical and geochemical characteristics of Caçapava do Sul alvikite and beforsite intrusions: a new Ediacaran carbonatite complex in southernmost Brazil. Ore Geology Reviews, 88:352-369. https://dx.doi.org/10.1016/j.oregeorev.2017.05.017
Chakhmouradian A.R. 2006. High-field-strength elements in carbonatitic rocks: geochemistry, crystal chemistry and significance for constraining the sources of carbonatites. Chemical Geology, 235:138-160. https://doi.org/10.1016/j. chemgeo.2006.06.008

Chmyz L., Arnaud N., Biondi J.C., Azzone R.G., Bosch D., Ruberti E. 2017. Ar-Ar ages, Sr-Nd isotope geochemistry and implications for the origin of the silicate rocks of the Jacupiranga ultramafic-alkaline complex (Brazil). Journal of South American Earth Sciences, 77:286309. https://doi.org/10.1016/j.jsames.2017.05.009

Church A.A. \& Jones A.P. 1995. Silicate-carbonate immiscibility at Oldoinyo Lengai. Journal of Petrology, 36:869-889. https://doi. org/10.1093/petrology/36.4.869

Clark T., Smith C.B., Bristow J.W., Skinner E.M.W., Viljoen K.S 1991. Isotopic and geochemical variation in kimberlites from the S-Western Craton Margin, Prieska area, South Africa. In: International Kimberlite Conference, 5., Araxá, Proceedings..., p. 46-48.

Comin-Chiaramonti P. \& Gomes C.B. (eds.). 1996. Alkaline magmatism in central-eastern Paraguay. Relationships with coeval magmatism in Brazil. São Paulo, Edusp/Fapesp, 464 p.

Comin-Chiaramonti P., Castorina F., Cundari A., Petrini R., Gomes C.B. 1995. Dykes and sills from Eastern Paraguay: Sr and Nd isotope systematics. In: Baer G. \& Heimann A. (eds.), Physics and chemistry of dykes. Rotterdam, Balkema, p. 267-278.

Comin-Chiaramonti P., Censi P., Cundari A., Gomes C.B. 1992. A silico-beforsitic flow from the Sapucai complex (Central-Eastern Paraguay). Geochimica Brasiliensis, 6:87-91.

Comin-Chiaramonti P., Cundari A., DeGraff J.M., Gomes C.B., Piccirillo E.M. 1999. Early Cretaceous-Tertiary magmatism in Eastern Paraguay (Western Paraná Basin): geological, geophysical and geochemical relationships. Journal of Geodynamics, 28:375-391. https://doi.org/10.1016/S0264-3707(99)00016-2

Comin-Chiaramonti P., Cundari A., Piccirillo E.M., Gomes C.B., Castorina F., Censi P., De Min A., Marzoli A., Petrini R., Speziale S., Velázquez V.F. 1997. Potassic and sodic igneous rocks from Eastern Paraguay: their origin from a lithospheric mantle and genetic relationships with the associated Paraná flood tholeiites. Journal of Petrology, 38:495-528. https://doi.org/10.1093/ petroj/38.4.495

Comin-Chiaramonti P., De Min A., Girardi V.A.V., Gomes C.B. 2014 Carbonatites and primary carbonates in the Rio Apa and Amambay regions, NE Paraguay. Lithos, 188:84-96. https://doi.org/10.1016/j. lithos.2013.10.027

Comin-Chiaramonti P., Girardi V.A.V., De Min A., Boggiani P.C., Correia C.T. 2011. Iron-rich formations at the Cerro Manomó region, southeastern Bolivia: remnant of a BIF? Episodes, 34:177-185.

Comin-Chiaramonti P., Gomes C.B., Castorina F., Censi P., Antonin P., Furtado S., Ruberti E., Scheibe LF. 2002. Anitápolis and Lages alkaline-carbonatite complexes, Santa Catarina state, Brazil: geochemistry and geodynamic implications. Revista Brasileira de Geociências, 32:43-58.

Comin-Chiaramonti P., Gomes C.B., Censi P., Gasparon M., Velázquez V.F. 2005a. Alkaline complexes from the Alto Paraguay province at the border of Brazil (Mato Grosso do Sul State) and Paraguay. In: Comin-Chiaramonti P. \& Gomes C.B. (eds.), Mesozoic to Cenozoic alkaline magmatism in the Brazilian Platform. São Paulo, Edusp/ Fapesp, p. 71-148

Comin-Chiaramonti P., Gomes C.B., Censi P., Speziale S. $2005 b$. Carbonatites from Southeastern Brazil: a model for the Carbon and Oxygen isotope variations. In: Comin-Chiaramonti P. \& Gomes C.B. (eds.), Mesozoic to Cenozoic alkaline magmatism in the Brazilian Platform. São Paulo, Edusp/Fapesp, p. 629-649. 
Comin-Chiaramonti P., Gomes C.B., Cundari A., Castorina F., Censi P. 2007a. A review of carbonatitic magmatism in the Paraná-AngolaEtendeka (PAN) system. In: Castelli D. \& Compagnoni R. (eds.), Periodico di Mineralogia, Special Issue, 76:25-78.

Comin-Chiaramonti P., Gomes C.B., Demin A., Ernesto M., Gasparon M. 2015. Magmatism along the High Paraguay river at the border of Brazil and Paraguay: a review and new constraints on emplacement ages. Journal of South American Earth Sciences, 58:72-81. http:// dx.doi.org/10.1016/j.jsames.2014.12.010

Comin-Chiaramonti P., Gomes C.B., De Min A., Ernesto M., Marzoli A., Riccomini C. 2007b. Eastern Paraguay: an overview of the Post-Paleozoic magmatism and geodynamical implications. Rendiconti Lincei, Scienze Fisiche e Naturali, 18:139-192. DOI: $10.1007 / \mathrm{BF} 02974464$

Comin-Chiaramonti P., Gomes C.B., Marques L.S., Censi P., Ruberti E., Antonini P. 2005c. Carbonatites from Southeastern Brazil: geochemistry, $\mathrm{O}-\mathrm{C}, \mathrm{Sr}-\mathrm{Nd}-\mathrm{Pb}$ isotopes. Relationships with the magmatism from the Paraná-Angola-Namibia Province. In: Comin-Chiaramonti P. \& Gomes C.B. (eds.), Mesozoic to Cenozoic alkaline magmatism in the Brazilian Platform. São Paulo, Edusp/Fapesp, p. 657-688.

Comin-Chiaramonti P., Gomes C.B., Ruberti E., Antonini P., Castorina F., Censi P. 2001. Mato Preto alkaline-carbonatite complex: geochemistry and isotope (O-C, Sr-Nd) constraints. Geochimica Brasiliensis, 15:23-34.

Comin-Chiaramonti P., Gomes C.B., Velázquez V.F., Censi P., Antonini F., Comin-Chiaramonti F., Punturo R. 2005d. Alkaline complexes from southerneastern Bolivia. In: Comin-Chiaramonti P. \& Gomes C.B. (eds.), Mesozoic to Cenozoic alkaline magmatism in the Brazilian Platform. São Paulo, Edusp/Fapesp, p. 159-211.

Comin-Chiaramonti P., Marzoli A., Gomes C.B., Milan A., Riccomini C., Velázquez V.F., Mantovani M.M.S., Renne P., Tassinari C.C.G., Vasconcelos P.M. 2007c. The origin of Post-Paleozoic magmatism in Eastern Paraguay. In: Foulger R.G. \& Jurdy D.M. (eds.), Plates, plumes and planetary processes. Geological Society of America, Special Paper, 430:603-633.

Comte D. \& Hasui Y. 1971. Geochronology of Eastern Paraguay by the potassium-argon method. Revista Brasileira de Geociências, 1:33-43.

Cordeiro P.F.O., Brod J.A., Dantas E.L., Barbosa E.S.R. 2010. Mineral chemistry, isotope geochemistry and petrogenesis of niobium-rich rocks from the Catalão I carbonatite-phoscorite complex, Central Brazil. Lithos, 118:223-237. https://doi.org/10.1016/j.lithos.2010.04.007

Cordeiro P.F.O., Brod J.A., Santos R.V., Dantas E.L., Oliveira C.G., Barbosa E.S.R. 2011. Stable (C, O) and radiogenic (Sr, Nd) isotopes of carbonates as indicators of magmatic and post-magmatic processes of phoscorite-series rocks and carbonatites from Catalão I, central Brazil. Contributions to Mineralogy and Petrology, 161:451-464. https://doi.org/10.1007/s00410-010-0542-y

Costa A.F.U., Fernandes L.A.D., Shukowsky W., Nardi L.V.S., Bittencourt M.F. 1995. Teste dos modelos tectônicos e de posicionamento do complexo granítico de Caçapava do Sul através de estudos de modelagem gravimétrica 3-D. Revista Brasileira de Geofísica, 13:91-101.

Coutinho J.M.V. 2008. Dyke swarms of the Paraná Triple Junction, Southern Brazil. Geologia USP, Série Científica, 8:29-52.

Coutinho J.M.V. \& Ens H.H. 1992. Diques lamprofíricos e diferenciados carbonatíticos da região de São Sebastião e Itanhaém, SP (Resultados preliminares). In: Congresso Brasileiro de Geologia, 37., São Paulo. Resumos Expandidos..., 1:512-513.

Danni J.C.M. 1994. Os picritos alcalinos da região de Iporá: implicações na gênese dos complexos do tipo central do sul de Goiás. Revista Brasileira de Geociências, 24:112-119.
Davies G.R., Driggs A.J., Nixon P.H. 2001. A non-cognate origin for the Gibeon kimberlite megacryst suite, Namibia: implications for the origin of Namibian kimberlites. Journal of Petrology, 42:159172. https://doi.org/10.1093/petrology/42.1.159

Davino A. 1975. Geologia da Serra de Araçoiaba, Estado de São Paulo. Boletim do Instituto de Geociências da USP, 6:129-144.

Deines P. 1989. Stable isotope variations in carbonatites. In: Bell K. (ed.), Carbonatites: genesis and evolution. London, Unwin Hyman Ltd., p. 301-359.

Dunworth E.A. \& Bell K. 1998. Melilitolites: a new scheme of classification. The Canadian Mineralogist, 36:895-903.

Ernesto M., Marques L.S., Piccirillo E.M., Molina E.C., Ussami N., Comin-Chiaramonti P. \& Bellieni G. 2002. Parana Magmatic Province-Tristan da Cunha plume system: Fixed versus mobile plume, petrogenetic considerations and alternative heat sources. Journal of Volcanology and Geothermal Research, 118(1-2):15-36. https://doi.org/10.1016/S0377-0273(02)00248-2

Ewart A., Marsh J.S., Milner S.C., Duncan A.R., Kamber B.S., Armstrong R.A. 2004. Petrology and geochemistry of Early Cretaceous bimodal continental flood volcanism of the NW Etendeka, Namibia. Part i: introduction, mafic lavas and re-evaluation of mantle source components. Journal of Petrology, 45:59-105. https://doi. org/10.1093/petrology/egg083

Faure G. 1986. Principles of isotope geology. New York, John Wiley \& Sons.

Fletcher C.J.N., Appleton J.D., Webb B.C., Basham I.R. 1981. Mineralization in the Cerro Manomó carbonatite complex, Eastern Bolivia. Transaction Institution of Mining and Metalurgy, Section B, Applied Sciences, 90:37-50.

Foley S.F. 1992. Petrological characterization of the source components of potassic magmas: geochemical and experimental constraints. Lithos, 28:187-204. https://doi. org/10.1016/0024-4937(92)90006-K

Furtado S.M.A. 1989. Petrologia do maciço alcalino de Anitápolis, SC. PhD Thesis, University of São Paulo, São Paulo. 245p.

Furtado S.M.A., Gomes C.B., Scheibe L.F. 1986. Ocorrência de foscoritos no maciço alcalino de Anitápolis. In: Congresso Brasileiro de Geologia, 34., Goiânia. Anais..., 4:1604-1614.

Gaspar J.C. 1989. Geologie et mineralogie du complexe carbonatique de Jacupiranga, Brésil. PhD Thesis, U.E.R. de Sciences Fondamentales et Apliquées, Université d'Orléans, Orléans, 344 p.

Gaspar J.C. \& Danni J.C.M. 1981. Aspectos petrográficos e vulcanológicos da província alcalino-carbonatítica de Santo Antônio da Barra, sudoeste de Goiás. Revista Brasileira de Geociências, 11:74-83.

Germann A., Marker A., Friedrich G. 1987. The alkaline complex of Jacupiranga, São Paulo, Brazil. Zentralblatt für Geologie und Paläontologie, 1:807-818.

Gibson S.A., Thompson R.N., Day J.A. 2006. Timescales and mechanisms of plume-lithosphere interactions: 40Ar/39Ar geochronology and geochemistry of alkaline igneous rocks from the Paraná-Etendeka large igneous province. Earth and Planetary Science Letters, 251(1-2):1-17. http://doi.org/10.1016/j. epsl.2006.08.004

Gibson S.A., Thompson R.N., Dickin A.P., Leonardos O.H. 1995a. High-Ti and low-Ti mafic potassic magmas: key to plumelithosphere interactions and continental flood-basalt genesis. Earth Planetary Science Letters, 136:149-165. https://doi. org/10.1016/0012-821X(95)00179-G 
Gibson S.A., Thompson R.N., Leonardos O.H., Dickin A.P., Mitchell J.G. 1995b. The Late Cretaceous impact of the Trindade mantle plume: evidence from large-volume, mafic, potassic magmatism in SE Brazil. Journal of Petrology, 36:189-229. https://doi.org/10.1093/ petrology/36.1.189

Gibson S.A., Thompson R.N., Leonardos O.H., Dickin A.P., Mitchell J.G. 1999. The limited extent of plume-lithosphere interactions during continental flood-basalt genesis: geochemical evidence from Cretaceous magmatism in Southern Brazil. Contributions to Mineralogy and Petrology, 137:147-169. https://doi.org/10.1007/ s004100050588

Gittins J. \& Harmer R.E. 2003. Myth and reality in the carbonatitesilicate rock association. Periodico di Mineralogia, 72(1):19-26.

Gomes C.B. 1970. Petrologia do maciço alcalino de Itapirapuã, São Paulo. Boletim do Instituto de Geociências e Astronomia, 1:77-188. http://dx.doi.org/10.11606/issn.2316-9001.v1iOp77-197

Gomes C.B. \& Comin-Chiaramonti P. 2005. Some notes on the Alto Paranaíba Igneous Province. In: Comin-Chiaramonti P. \& Gomes C.B. (eds.), Mesozoic to Cenozoic alkaline magmatism in the Brazilian Platform. São Paulo, Edusp/Fapesp, p. 317-340.

Gomes C.B. \& Comin-Chiaramonti P. (eds.). 2017. Magmatismo alcalino continental da região meridional da Plataforma Brasileira. São Paulo, Edusp/Fapesp, 608 p.

Gomes C.B., Comin-Chiaramonti P., Velázquez V.F., Orué D. 1996b. Alkaline magmatism in Paraguay: a review. In: Comin-Chiaramonti P. \& Gomes C.B. (eds.). Alkaline magmatism in central-eastern Paraguay. Relationships with coeval magmatism in Brazil. São Paulo: Edusp/Fapesp. p. 35-56.

Gomes C.B. \& Cordani U.G. 1965. Geocronologia do maciço alcalino de Itapirapuã (SP). Anais da Academia Brasileira de Ciências, 37:497-501

Gomes C.B. \& Dutra C.V. 1969. A short note about the carbonatites from Itapirapuã, São Paulo. Anais da Academia Brasileira de Ciências, 41:195-198.

Gomes C.B. \& Dutra C.V. 1970. Some geochemical features of the alkaline rocks of Itapirapuã, São Paulo. Anais da Academia Brasileira de Ciências, 42:521-534.

Gomes C.B., Comin-Chiaramonti P., Velázquez V.F. 2013. A synthesis on the alkaline magmatism of Eastern Paraguay. Brazilian Journal of Geology, 43:745-761. DOI: 10.5327/Z2317-488920130004000012

Gomes C.B., Morbidelli L., Ruberti E., Comin-Chiaramonti P. 1996a. Comparative aspects between Post-Palaeozoic alkaline rocks from the western and eastern margins of the Paraná Basin. In: CominChiaramonti P. \& Gomes C.B. (eds.), Alkaline magmatism in centraleastern Paraguay. Relationships with coeval magmatism in Brazil. São Paulo, Edusp/Fapesp, p. 249-274.

Gomes C.B., Ruberti E., Azzone R.G., Vasconcelos P.M, Sato K., Enrich G.E.R. 2018. New age determinations for the Banhadão and Itapirapuã complexes in the Ribeira Valley, southern Brazil. Brazilian Journal of Geology, in press.

Gomes C.B., Ruberti E., Comin-Chiaramonti P., Azzone R.G. 2011a. Alkaline magmatism in the Ponta Grossa Arch, SE Brazil: a review. Journal of South American Earth Sciences, 32:152-168. https://doi. org/10.1016/j.jsames.2011.05.003

Gomes C.B., Ruberti E., Morbidelli L. 1990. Carbonatite complexes from Brazil: a review. Journal of South American Earth Sciences, 3:51-63. https://doi.org/10.1016/0895-9811(90)90017-U

Gomes C.B., Velázquez V.F., Azzone R.G., Paula G.S. 2011b. Alkaline magmatism in the Amambay area, NE Paraguay: the Cerro Sarambí complex. Journal of South American Earth Sciences, 32:75-95. https://doi.org/10.1016/j.jsames.2011.04.004
Gomide C.S., Brod J.A., Junqueira-Brod T.C., Buhn B., Santos R.V. Barbosa E.S.R., Cordeiro P.F.O., Palmieri M., Grasso C.B., Torres M.G. 2013. Sulfur isotopes from Brazilian alkaline complexes. Chemical Geology, 341:38-49. https://doi.org/10.1016/j. chemgeo.2013.01.006

Gomide C.S., Brod J.A., Vieira L.C., Junqueira-Brod T.C., Petrinovic I.A., Santos R.V., Barbosa E.S.R., Mancini L.H. 2016. Stable (C, O, S) isotopes and whole-rock geochemistry of carbonatites from Alto Paranaíba Igneous Province, SE Brazil. Brazilian Journal of Geology, 46:351-376. http://dx.doi.org/10.1590/2317-4889201620150059

Grasso C.B. 2010. Petrologia do complexo alcalino de Serra Negra, MG. MSc Dissertation, University of Brasília, Brasília. 209p.

Guarino V., Azzone R.G., Brotzu P., Gomes C.B., Melluso L., Morbidelli L. Ruberti E., Tassinari C.C.G., Brilli M. 2012. Magmatism and fenitization in the Cretaceous potassium-alkaline-carbonatitic complex of Ipanema, São Paulo State, Brazil. Mineralogy and Petrology, 104:43-61. DOI: 10.1007/s00710-011-0168-4

Guarino V., Wu F.-Y., Lustrino M., Melluso L., Brotzu P., Gomes C.B., Ruberti E., Tassinari C.C.G., Svisero D.P. 2013. U-Pb ages, Sr-Nd isotope geochemistry, and petrogenesis of kimberlites, kamafugites and phlogopite-picrites of the Alto Paranaíba Igneous Province, Brazil. Chemical Geology, 353:65-82. https://doi.org/10.1016/j. chemgeo.2012.06.016

Guarino V., Wu F.-Y., Melluso L., Gomes C.B., Tassinari C.C.G., Rubert E., Brilli M. 2017. U-Pb ages, geochemistry C-O-Nd-Sr-Hf isotopes and petrogenesis of the Catalão II carbonatitic complex (Alto Paranaíba Igneous Province, Brazil): implications for regional-scale heterogeneities in Brazilian carbonatite associations. International Journal of Earth Sciences, 106:1963-1989. https://doi.org/10.1007/ s00531-016-1402-4

Guimarães I.G., Amaral M.A.M., Garcia I.R.A. 1980. Uncompahgrito de Tapira, MG. In: Congresso Brasileiro de Geologia, 31., Camboriú. Anais..., p. 2050-2058.

Haggerty S.E. \& Mariano A.N. 1983. Strontian loparite and strontiochevkinite: two new minerals in rheomorphic tenites from the Paraná Basin carbonatites, South America. Contributions to Mineralogy and Petrology, 84:365-381.

Hart S.R. 1984. A large-scale isotope anomaly in the Southern Hemisphere. Nature, 309:753-757. DOI: 10.1038/309753a0

Hart S.R., Gerlach D.C., White W.M. 1986. A possible new Sr$\mathrm{Nd}-\mathrm{Pb}$ mantle array and consequences for mantle mixing. Geochimica et Cosmochimica Acta, 50:1551-1557. https:/doi. org/10.1016/0016-7037(86)90329-7

Hart S.R., Hauri E.H., Oschmann I.A., Whitehead J.A. 1992. Mantle plumes and entrainement isotopic evidence. Science, 256:517-520.

Hart S.R. \& Zindler A. 1989. Constraints on the nature and the development of chemical heterogeneities in the mantle. In: Peltier W.R. (ed.), Mantle convection plate tectonics and global dynamics. New York, Gordon and Breach Sciences Publishers, p. 261-388.

Hasui Y., Sadowski G.R., Suguio K., Fuck R.A. 1975. The Phanerozoic tectonic evolution of the western Minas Gerais. Anais da Academia Brasileira de Ciências, 47:431-438.

Herz N. 1977. Timing of spreading in the South Atlantic: information from Brazilian alkali rocks. Geological Society of America Bulletin, 88:101-112

Hoernle K., Tilton G., Le Bas M.J., Duggen S., Garbe-Schönberg D. 2002. Geochemistry of oceanic carbonatites compared with continental carbonatites: mantle recycling of oceanic crustal carbonate. Contributions to Mineralogy and Petrology, 142:520-542. DOI: 10.1007/s004100100308 
Huang J.-M., Hawkesworth C.J., Van Calsteren P., McDermott F, 1995. Geochemical characteristics and origin of the Jacupiranga carbonatites. Chemical Geology, 119:79-99. https://doi. org/10.1016/0009-2541(94)00093-N

Issa Filho A., Lima P.R.A.S., Souza O.M. 1984. Aspectos da geologia do complexo carbonatítico do Barreiro, Araxá, MG, Brasil. Companhia Brasileira de Metalurgia e Mineração, p. 19-44

Jenkis II, R.E. 1987. Geology of the Clugger-fluorite deposit, Mato Preto, Paraná, Brazil. Revista Brasileira de Geociências, 17:288-294.

Junqueira-Brod T.C., Brod J.A., Gibson S.A., Thompson R.N. 2000. Mineral chemistry of kamafugites and related rocks from Águas Emendadas region, Goiás State. Revista Brasileira de Geociências, 30:403-407.

Junqueira-Brod T.C., Roig H.L., Gaspar J.C., Brod J.A., Meneses P.R. 2002. A província alcalina de Goiás e extensão do seu vulcanismo kamafugítico. Revista Brasileira de Geociências, 32:559-566

Keller J. \& Hoefs J. 1995. Stable isotope characteristics of recent natrocarbonatites from Oldoinyo Lengai. In: Bell K. \& Keller J. (eds.), Carbonatite volcanism: Oldoinyo Lengai and the petrogenesis of natrocarbonatites. Berlin, Springer, p. 113-123.

Kjarsgaard B.A. \& Hamilton D.L. 1988. Liquid immiscibility and the origin of alkali-poor carbonatites. Mineralogical Magazine, 52:43-55. DOI: 10.1180/minmag.1988.052.364.04

Kjarsgaard B.A. \& Hamilton D.L. 1989. The genesis of carbonatites by immiscibility. In: Bell K. (ed.), Carbonatite: Genesis and Evolution. London, Unwin Hyman, p. 388-404.

Knecht T. 1960. Notas preliminares sobre novas ocorrências de rochas alcalinas no Estado de São Paulo. Boletim da Sociedade Brasileira de Geologia, 9:71-76.

Lapido-Loureiro F.E. \& Tavares J.R. 1983. Duas novas ocorrências carbonatíticas: Mato Preto e Barra do Itapirapuã. Revista Brasileira de Geociências, 13:7-11.

Le Bas M.J. 2008. Fenites associated with carbonatites. The Canadian Mineralogist, 46:915-932. DOI: 10.3749/canmin.46.4.915

Le Roex A.P. 1985. Geochemistry, mineralogy and magmatic evolution of the basaltic and trachytic lavas from Gough Island, South Atlantic. Journal of Petrology, 26:149-186. https://doi. org/10.1093/petrology/26.1.149

Le Roex A.P., Cliff R.A., Adair B.J.J. 1990. Tristan da Cunha, South Atlantic: geochemistry and petrogenesis of a basanite-phonolite lava series. Journal of Petrology, 31:779-812. https://doi.org/10.1093/ petrology/31.4.779

Lee W.J. \& Wyllie P.J. 1994. Experimental data bearing on liquid immiscibility, crystal fractionation, and the origin of calciocarbonatites. International Geology Review, 36:797-819. https://doi.org/10.1080/00206819409465489

Lee W.J. \& Wyllie P.J. 1996. Liquid Immiscibility in the join $\mathrm{NaAlSi}_{3} \mathrm{O}_{8}-\mathrm{CaCO}_{3}$ to $2.5 \mathrm{GPa}$ and the origin of calciocarbonatite magmas. Journal of Petrology, 37:1125-1152. https://doi. org/10.1093/petrology/37.5.1125

Lee W.J. \& Wyllie P.J. 1997. Liquid immiscibility between nephelinite and carbonatite from 2.5 to $1.0 \mathrm{GPa}$ compared with mantle melt compositions. Contributions to Mineralogy and Petrology, 127:1-16. http://dx.doi.org/10.1007/s004100050261

Lee W.J. \& Wyllie P.J. 1998a. Petrogenesis of carbonatite magmas from mantle to crust, constrained by the system $\mathrm{CaO}-\left(\mathrm{MgO}+\mathrm{FeO}^{*}\right)$ $\left(\mathrm{Na}_{2} \mathrm{O}+\mathrm{K}_{2} \mathrm{O}\right)-\left(\mathrm{SiO}_{2}+\mathrm{Al}_{2} \mathrm{O}_{3}+\mathrm{TiO}_{2}\right)-\mathrm{CO}_{2}$. Journal of Petrology, 39:495517. https://doi.org/10.1093/petroj/39.3.495
Lee W.J. \& Wyllie P.J. 1998b. Processes of crustal carbonatite formation by liquid immiscibility and differentiation, elucidated by model systems. Journal of Petrology, 39:2005-2013. https://doi. org/10.1093/petroj/39.11-12.2005

Leinz V. 1940. Petrologia das jazidas de apatita de Ipanema. Departamento Nacional da Produção Mineral. Rio de Janeiro, Ministério da Agricultura. 52p.

Livieres R.A. \& Quade H. 1987. Distribución regional y asentamiento tectónico de los complejos alcalinos del Paraguay. Zentralblatt für Geologie und Paläontologie, Part I, 7:791-805.

Machado Jr. D.L. 1991. Geologia e aspectos metalogenéticos do complexo alcalino-carbonatítico de Catalão II (GO). PhD Thesis, Universidade de Campinas, Campinas, 102 p.

Maciel L.A.C. 2016. Rochas alcalinas do Rio Grande do Sul: controles tectônicos e mineralização associadas. In: SIMEXMIN, Ouro Preto. Boletim de Resumos.

Mariano A.N. 1989. Economic geology of Rare Earth Elements. Reviews on Mineralogy, 21:309-348.

Mariano A. \& Marchetto M. 1991. Serra Negra and Salitre carbonatite alkaline igneous complex. In: 5th International Kimberlite Conference, Araxá. Field Guide Book. p.74-79.

Marques L.S., Dupré B., Piccirillo E.M. 1999. Mantle source compositions of the Paraná Magmatic Province (Southern Brazil): evidence from trace element and $\mathrm{Sr}-\mathrm{Nd}-\mathrm{Pb}$ isotope geochemistry. Journal of Geodynamics, 28:439-458. https:/doi.org/10.1016/ S0264-3707(99)00020-4

Marques L.S., Ulbrich M.N.C., Ruberti E., Tassinari C.C.G. 2000 Petrology, geochemistry and Sr-Nd isotopes of the Trindade and Martin Vaz volcanic rocks (South Atlantic Ocean). Journal of Volcanology and Geothermal Research, 93:191-216. https://doi. org/10.1016/S0377-0273(99)00111-0

McDonough W.F. \& Sun S. 1995. The Composition of the Earth. Chemical Geology, 120:223-253. https://doi. org/10.1016/0009-2541(94)00140-4

Melcher G.C. \& Coutinho J.M.V. 1966. Rochas alcalinas e carbonatito de Anitápolis, Estado de Santa Catarina. Boletim da Sociedade Brasileira de Geologia, 15:59-93.

Melcher G.C. 1966. The carbonatites of Jacupiranga, São Paulo, Brazil. In: Tuttle O.F. \& Gittins J. (eds.), Carbonatites. New York, Interscience, p. 169-181.

Melluso L., Lustrino M., Ruberti E., Brotzu P., Gomes C.B., Morbidelli L., Morra V., Svisero D.P., D'Amelio F. 2008. Major- and trace-element composition of olivine, perovskite, clinopyroxene, Cr-Fe-Ti oxides, phlogopites and host kamafugites and kimberlites, Alto Paranaíba, Brazil. The Canadian Mineralogist, 46:19-40. DOI: 10.3749/ canmin.46.1.19

Menezes Jr. L.A.D. \& Martins J.M. 1984. The Jacupiranga mine, São Paulo, Brazil. The Mineralogical Record, 15:261-270.

Meyer H.O.A., Blaine L.G., Svisero D.P., Craig B.S. 1994. Alkaline intrusions in western Minas Gerais. In: International Kimberlite Conference, 5., Araxá. Proceedings..., p. 140-155.

Mitchell R.H. 2005. Carbonatites and carbonatites and carbonatites. The Canadian Mineralogist, 43:2049-2068. https://doi.org/10.2113/ gscanmin.43.6.2049

Monteiro C.F., Toniolo J.A., Abram M.B. 2016. Carbonatitos associados ao Escudo Sul-Riograndense, Rio Grande do Sul. In: Abram M.B., Bahiense J.C., Almeida R.C. (eds.), Projeto Fosfato Brasil - Parte II. CPRM. Informe de Recursos Minerais, Série Insumos Minerais para Agricultura, 17:433-449. 
Moraes L.C. 1984. Petrologia, estratigrafia e potencial diamantífero da suíte vulcânica alcalina da região de Santo Antônio da Barra, Goiás. MSc Dissertation, Universidade de Brasília, Brasília. 133p.

Moraes L.C. 1988. Aspectos petrológicos do magmatismo alcalino cretáceo de Santo Antônio da Barra, GO. Revista Brasileira de Geociências, 18:33-42.

Morbidelli L., Beccaluva L., Brotzu P., Conte A.M., Garbarino C., Gomes C.B., Macciotta G., Ruberti E., Scheibe L.F., Traversa G. 1986. Petrological and geochemical studies of alkaline rocks from continental Brazil. 3. Fenitization of jacupirangite by carbonatite magmas in Jacupiranga complex, SP. Periodico di Mineralogia, 55:261-295.

Morbidelli L., Gomes C.B., Beccaluva L., Brotzu P., Conte A.M., Ruberti E., Traversa G. 1995. Mineralogical, petrological and geochemical aspects of alkaline and alkaline-carbonatite associations from Brazil. Earth-Science Reviews, 39:135-168. https://doi. org/10.1016/0012-8252(95)00031-3

Morbidelli L., Gomes C.B., Beccaluva L., Brotzu P., Garbarino C., Riffel B. F. Ruberti E., Traversa G. 1997. Parental magma characterization of Salitre cumulate rocks (Alto Paranaíba Alkaline Province, Brazil) as inferred from mineralogical, petrographic and geochemical data. International Geology Review, 39:723-743. https://doi. org/10.1080/00206819709465298

Natali C., Beccaluva L., Bianchini G., Siena F. 2018. Coexistence of alkaline-carbonatite complexes and high-MgO CFB in the ParanáEtendeka province: Insights on plume-lithosphere interactions in the Gondwana realm. Lithos, 296-299:54-66. https://doi.org/10.1016/j. lithos.2017.11.001

Nelson D.R., Chivas A.R., Chappell B.W., McCulloch M.T. 1988. Geochemical and isotopic systematics in carbonatites and implications for the evolution of ocean-island sources. Geochimica et Cosmochimica Acta, 52:1-17. https://doi. org/10.1016/0016-7037(88)90051-8

Oliveira I.L., Brod J.A., Cordeiro P.F.O., Dantas E.L., Mancini L.H. 2017. Insights into the late-stage differentiation processes of the Catalão I carbonatite complex in Brazil: New Sr-Nd and C-O isotopic data in minerals from niobium ores. Lithos, 274-275:214-224. DOI 10.1016/j.lithos.2016.12.034

Otto J.W. \& Wyllie P.J. 1993. Relationships between silicate melts and carbonate precipitating melts in $\mathrm{CaO}-\mathrm{MgO}-\mathrm{SiO}_{2}-\mathrm{CO}_{2}-\mathrm{H}_{2} \mathrm{O}$ at 2 kbar. Mineralogy and Petrology, 48:343-365.

Pena G.S. 1974. Geologia da Área do Projeto Goiânia II, Sudoeste de Goiás. In: Congresso Brasileiro de Geologia, 28., Porto Alegre. Anais.. 4:37-50.

Philipp R.P., Viero A.P., Comin-Chiaramonti P., Gomes C.B. 2005 Mesozoic alkaline rocks of Rio Grande do Sul. In: Comin-Chiaramonti P. \& Gomes C.B. (eds.), Mesozoic to Cenozoic alkaline magmatism in the Brazilian Platform. São Paulo, Edusp/Fapesp, p. 573-590.

Piccirilo E.M. \& Melf A.J. 1988. The Mesozoic flood volcanism of the Paraná Basin: petrogenetic and geophysical aspects. São Paulo, IAGUSP, 600p.

Riccomini C., Velázquez V.F., Gomes C.B. 2005. Tectonic controls of the Mesozoic and Cenozoic alkaline magmatism in the CentralSoutheastern Brazilian Platform. In: Comin-Chiaramonti P. \& Gomes C.B. (eds.), Mesozoic to Cenozoic alkaline magmatism in the Brazilian Platform. São Paulo, Edusp/Fapesp, p. 31-56.

Richardson S.H., Gurney J.J., Erlank A.J., Harris J.W. 1984. Origin of diamonds in old enriched mantle. Nature, 310:198-202. DOI: 10.1038/310198a0

Rocha A.M.R., Dorneles N.T., Gindri M.D., Vargas F.M., CervaAlves T., Benetti F.A. 2013. Descoberta dos carbonatitos Picada dos Tocos e Passo Feio e o potencial para fosfato e ETRs, Caçapava do Sul, Rio Grande do Sul. In: Brazilian Symposium of Metallogeny - The New Brazilian Mineral Deposits, 3., Gramado. Boletim de Resumos.

Roden M.F., Murphy V.R., Gaspar J.C. 1985. Sr and Nd isotopic composition of the Jacupiranga carbonatite. Journal of Geology. 93:212-220. https://doi.org/10.1086/628943

Rodrigues C.S. \& Lima P.R.A.S. 1984. Complexos carbonatíticos do Brasil: geologia. Araxá, Companhia Brasileira de Metalurgia e Mineração, p. 1-17

Rodrigues E.P.O. 1985. O complexo alcalino de Anitápolis: um estudo petrológico. PhD Thesis, Universidade de São Paulo, São Paulo. 174p.

Ruberti E. 1998. Petrologia e geoquímica das suítes carbonatíticas de Mato Preto (PR) e da Barra do Itapirapuã (PR/SP), Brasil. Thesis, University of São Paulo, São Paulo.

Ruberti E., Castorina F., Censi P., Comin-Chiaramonti P., Gomes C.B., Antonini P., Andrade F.R.D. 2002. The geochemistry of the Barra do Itapirapuã carbonatite (Ponta Grossa Arch, Brazil): a multiple stockwork. Journal of South American Earth Sciences, 15:215-228. https://doi.org/10.1016/S0895-9811(02)00031-7

Ruberti E., Castorina F., Censi P., Gomes C.B., Speziale S., CominChiaramonti P. 1997. REE-O-C-Sr-Nd in carbonatites from Barra do Itapirapuã and Mato Preto (Southern Brazil). In: South American Symposium on Isotope Geology, 1., Campos do Jordão. Short Papers... p. 271-275.

Ruberti E., Enrich G.E.R., Gomes C.B., Comin-Chiaramonti P. 2008. Hydrothermal REE fluorocarbonate mineralization at Barra do Itapirapuã, a multiple stockwork carbonatite, Southern Brazil. The Canadian Mineralogist, 46:901-914. https://doi.org/10.3749/ canmin.46.4.901

Ruberti E., Gomes C.B., Comin-Chiaramonti P. 2005. The alkaline magmatism from the Ponta Grossa Arch. In: Comin-Chiaramonti P. \& Gomes C.B. (eds.), Mesozoic to Cenozoic alkaline magmatism in the Brazilian Platform. São Paulo, Edusp/Fapesp, p. 473-522.

Ruberti E., Marguti R.L., Gomes C.B. 1991. O complexo carbonatítico de Jacupiranga: informações gerais. In: Congresso Brasileiro de Geoquímica, 3./Congresso de Geoquímica dos Países de Língua Portuguesa, 1., São Paulo. Guia de Excursões... p. 1-20.

Ruberti E., Scheibe L.F., Gomes C.B. 1988. The Jacupiranga alcaline complex. In: International Conference on the Geochemical Evolution of the Continental Crust, Poços de Caldas. Extended Abstracts... p.11-25.

Rugenski A., Mantovani M.S.M., Shukowsky W. 2006. Investigação gravimétrica do complexo alcalino de Ipanema, São Paulo, Brasil Geologia USP, Série Científica, 6:13-24. http://dx.doi.org/10.5327/ S1519-874X2006000200002

Sadowski G.R. 1987. A possible relation between pulses of platform activation and plate kinematics. Tectonophysics, 143:43-57. https:// doi.org/10.1016/0040-1951(87)90077-1

Santos R.V. 1988. Geologia e geoquímica do depósito de fluorita do complexo carbonatítico de Mato Preto, Paraná, Brasil. MSc Dissertation, Universidade de Brasília, Brasília. 144p.

Santos R.V. \& Clayton R.N. 1995. Variations of oxygen and carbon isotopes in carbonatites - A study of Brazilian alkaline complexes. Geochimica et Cosmochimica Acta, 59:1339-1352. https:/doi. org/10.1016/0016-7037(95)00048-5

Santos R.V., Dardenne M.A., Matsui E. 1990. Geoquímica de isótopos de carbono e oxigênio dos carbonatitos do complexo alcalino de Mato Preto, Paraná, Brasil. Revista Brasileira de Geociências, 20(1-4):153-158 
Santos R.V., Dardenne M.A., Oliveira C.G. 1996. Rare Earth Elements geochemistry of fluorite from the Mato Preto carbonatite complex. Revista Brasileira de Geociências, 26:81-86.

Sasada T., Hiyagon H., Bell H., Edbihara M. 1997. Mantle-derived noble gases in carbonatites. Geochimica et Cosmochimica Acta, 61:4219-4228. https://doi.org/10.1016/S0016-7037(97)00202-0

Scheibe L.F. 1986. Geologia e petrologia do distrito alcalino de Lages, SC, Brasil. PhD Thesis, Universidade de São Paulo, São Paulo, 224 p.

Scheibe L.F. \& Formoso M.L.L. 1982. Contribuição da geoquímica das Terras Raras à caracterização dos carbonatitos da Fazenda Varela, Lages, SC. Revista Brasileira de Geociências, 12:553-561.

Scheibe L.F., Furtado S.M.A., Comin-Chiaramont P., Gomes C.B. 2005. Cretaceous alkaline magmatism from Santa Catarina State, Southern Brazil. In: Comin-Chiaramontim P. \& Gomes C.B. (eds.), Mesozoic to Cenozoic alkaline magmatism in the Brazilian Platform. São Paulo, Edusp/Fapesp, p. 523-571.

Sgarbi P.B.D. 1998. Mineralogia e petrologia dos kamafugitos da região de Santo Antônio da Barra, Sudoeste de Goiás. PhD Thesis, Universidade Federal do Rio de Janeiro, Rio de Janeiro. 214p.

Sgarbi P.B.D., Gaspar J.C., Valença J.G. 2000. Brazilian kamafugites. Revista Brasileira de Geociências, 30:417-420.

Siebel W., Becchio R., Wolker F., Hansen M.A.F., Viramonte J., Trumbull R.B., Haase G., Zimmer M. 2000. Trindae and Martín Vaz islands, South Atlantic: isotopic (Sr, Nd, $\mathrm{Pb}$ ) and trace element constraints on plume related magmatism. Journal of South American Earth Sciences, 13:79-103. https://doi.org/10.1016/S0895-9811(00)00015-8

Smith C.B. 1983. Pb, Sr and Nd isotopic evidence for sources of Southern African Cretaceous kimberlites. Nature, 304:51-54. DOI: 10.1038/304051a0

Smith C.B., Gurney J.J., Skinner E.M.W., Clement C.R., Ebrahim N. 1985. Geochemical character of Southern African kimberlites: a new approach based on isotopic constraints. Transactions of the Geological Society of South Africa, 88:267-280.

Song W., Xu C., Chakhmouradian A.R., Kynicky J., Huang K., Zhang Z. 2017. Carbonatites of Tarim (NW China): first evidence of crustal contribution in carbonatites from a large igneous province. Lithos, 282-283:1-9. https://doi.org/10.1016/j.lithos.2017.02.018

Sonoki I.K. \& Garda G.M. 1988. Idades K-Ar de rochas alcalinas do Brasil Meridional e Paraguai Oriental: compilação e adaptação às novas constantes de decaimento. Boletim do Instituto de Geociências USP, Série Científica, 19:63-85. DOI: 10.11606/issn.2316-8986. v19i0p63-85

Souza Filho J.G.C. (1974) Prospecção de urânio nas chaminés alcalinas de Serra Negra e Salitre, MG. Boletim do Ministério de Minas e Energia. Rio de Janeiro, Comissão Nacional de Energia Nuclear. v.9. 41p.

Speziale S., Censi P., Comin-Chiaramonti P., Ruberti E., Gomes C.B. 1997. Oxygen and carbon isotopes in the Barra do Itapirapuã and Mato Preto carbonatites (Southern Brazil). Mineralogica et Petrographica Acta, 40:1-21.

Sun S.S. \& McDonough W.F. 1989. Chemical and isotopic systematics of oceanic basalts. In: Saunders D. \& Norry M.J. (eds.), Magmatism in oceanic basins. Geological Society of London, Special Publication, 42:313-345.

Taylor Jr. H.P., Frechen J., Degens E.T. 1967. Oxigen and carbon isotope studies of carbonatites from Laacher See district, West Germany and Alnø District, Sweden. Geochimica et Cosmochimica Acta, 31:407-430. https://doi. org/10.1016/0016-7037(67)90051-8
Thompson N. 1982. Magmatism of the British Tertiary Volcanic Province (Carnegie Review Article). Scottish Journal of Geology, 18:49-107. https://doi.org/10.1144/sjg18010049

Thompson R.N., Gibson S.A., Mitchell J.G., Dickin A.P., Leonardos O.H., Brod J.A., Greenwood J.C. 1998. Migrating CretaceousEocene magmatism in the Serra do Mar Alkaline Province, SE, Brazil: melts from the deflected Trindade mantle plume? Journal of Petrology, 39:1493-1526.

Toniolo J.A., Remus M.V.D., Parisi G.N., Dani N. 2013. Dois eventos carbonatíticos temporalmente distintos no RS: tipos linear e central. In: Simpósio Sul-Brasileiro de Geologia, 8., Foz do Iguaçu. Resumos...

Toyoda K., Horiuchi H., Tokomani M. 1994. Dupal anomaly of Brazilian carbonatites: geochemical correlations with hotspots in the South Atlantic and implications for the mantle source. Earth and Planetary Science Letters, 126:315-331. https://doi. org/10.1016/0012-821X(94)90115-5

Traversa G., Barbieri M., Beccaluva L., Coltorti M., Conte A.M., Garbarino C., Gomes C.B., Macciotta G., Morbidelli L., Ronca S., Scheibe L.F. 1996. Mantle sources and differentiation of alkaline magmatic suite of Lages, Santa Catarina, Brazil. European Journal of Mineralgoy, 8:193-208.

Traversa G., Gomes C.B., Brotzu P., Buraglini N., Morbidelli L., Macciotta G., Morbidelli L., Principato M.S., Ronca S., Ruberti E. 2001. Petrography and mineral chemistry of carbonatites and mica-rich rocks from the Araxá complex (Alto Paranaíba Province, Brazil). Anais da Academia Brasileira de Ciências, 73:71-98. http://dx.doi.org/10.1590/S0001-37652001000100008

Traversa G., Schelbe L.F., Barbieri M., Beccaluva L., Coltorti M., Conte A.C., Garbarino C., Gomes C.B., Macciotta G., Morbidelli L., Ronca S. 1994. Petrology and mineral chemistry of the alkaline district of Lages, SC, Brazil. Geochimica Brasiliensis, 8:179-214.

Ulbrich H.H. \& Gomes C.B. 1981. Alkaline rocks from continental Brazil. Earth-Science Reviews, 17:135-154. https://doi. org/10.1016/0012-8252(81)90009-X

Ulbrich H.H., Garda G.M., Ulbrich M.N.C. 1991. Avaliação das idades K-Ar dos maciços alcalinos do Brasil Sul-Oriental e Paraguai Oriental. Boletim Instituto de Geociências USP, Publicação Especial, 9:87-91. http://dx.doi.org/10.11606/issn.2317-8078. v0i9p87-92

Ulbrich H.H.G.J., Demaiffe D., Vlach S.R.F., Ulbrich M.N.C. 2005. Structure and origin of the Poços de Caldas alkaline massif, SE Brazil. In: Comin-Chiaramonti P. \& Gomes C.B. (eds.), Mesozoic to Cenozoic alkaline magmatism in the Brazilian Platform. São Paulo, Edusp/Fapesp, p. 367-418.

Ulbrich H.H.G.J., Vlach S.R.F., Ulbrich M.N.C., Kawashita K. 2002. Penecontemporaneous syenitic-phonolitic and basic-ultrabasiccarbonatitic rocks at the Poços de Caldas alkaline massif, SE Brazil: genetic and geochronologic evidence. Revista Brasileira de Geociências, 32:15-26.

Velázquez V.F., Riccomini C., Gomes C.B., Figueredo L., Figueredo C. 1998. Relações tectônicas do magmatismo alcalino do Paraguai Oriental. Revista do Instituto Geológico, 19:41-48. http://dx.doi. org/10.5935/0100-929X.19980005

Vlach S.R.F., Vilalva F.C.J., Ulbrich M.N.C, Ulbrich H.H.G.J., Vasconcelos P.M. 2003. Phlogopite from carbonatitic veins associated with the Poços de Caldas alkaline massif, SE Brazil: mineralogy and ${ }^{40} \mathrm{Ar} /{ }^{39} \mathrm{Ar}$ dating by the laser step heating method. In: South American Symposium on Isotope Geology, 6., Salvador. Short Papers..., v. 2, p. 702-705. 
Walter A.V., Flicoteaux R., Parron C., Loubet M., Nahon D. 1995. Rare-Earth Elements and isotopes ( $\mathrm{Sr}, \mathrm{Nd}, \mathrm{O}, \mathrm{C}$ ) in minerals from the Juquiá carbonatite (Brazil): tracers of a multistage evolution. Chemical Geology, 120:27-44. https://doi. org/10.1016/0009-2541(94)00101-D

Woolley A.R. 1987. Alkaline rocks and carbonatites of the world. Part I: North and South America. London, British Museum (Natural History), $216 \mathrm{p}$.

Woolley A.R. \& Kempe D.R.C. 1989. Carbonatites: nomenclature, average chemical compositions, and element distribution. In:
Bell K. (ed.), Carbonatites: genesis and evolution. London, Unwin Hyman Ltd., p. 1-14.

Woolley A.R. \& Kjarsgaard B.A. 2008. The paragenetic types of carbonatite as indicated by the diversity and relative abundances of associated silicate rocks: evidence from a global database. The Canadian Mineralogist, 46:741-752. DOI: 10.3749/ canmin.46.4.741

Zindler A. \& Hart S.R. 1986. Chemical geodynamics. Annual Review of Earth and Planetary Sciences, 14:493-571. https://doi. org/10.1146/annurev.ea.14.050186.002425 